\title{
Sex Differences in Kappa Opioid Receptor Function and Their Potential Impact on Addiction
}

\author{
Elena H. Chartoff* and Maria Mavrikaki \\ Department of Psychiatry, Harvard Medical School, McLean Hospital, Belmont, MA, USA
}

\section{OPEN ACCESS}

Edited by:

Styliani (Stella) Vlachou,

Dublin City University, Ireland

Reviewed by:

Glenn W. Stevenson,

University of New England, USA

Regina A. Mangieri,

The University of Texas at Austin, USA

*Correspondence:

Elena H. Chartoff

echartoff@mclean.harvard.edu

Specialty section:

This article was submitted to

Neuropharmacology,

a section of the journal

Frontiers in Neuroscience

Received: 24 September 2015 Accepted: 23 November 2015 Published: 16 December 2015

Citation:

Chartoff EH and Mavrikaki M (2015)

Sex Differences in Kappa Opioid Receptor Function and Their Potential Impact on Addiction.

Front. Neurosci. 9:466. doi: 10.3389/fnins.2015.00466
Behavioral, biological, and social sequelae that lead to drug addiction differ between men and women. Our efforts to understand addiction on a mechanistic level must include studies in both males and females. Stress, anxiety, and depression are tightly linked to addiction, and whether they precede or result from compulsive drug use depends on many factors, including biological sex. The neuropeptide dynorphin (DYN), an endogenous ligand at kappa opioid receptors (KORs), is necessary for stress-induced aversive states and is upregulated in the brain after chronic exposure to drugs of abuse. KOR agonists produce signs of anxiety, fear, and depression in laboratory animals and humans, findings that have led to the hypothesis that drug withdrawal-induced DYN release is instrumental in negative reinforcement processes that drive addiction. However, these studies were almost exclusively conducted in males. Only recently is evidence available that there are sex differences in the effects of KOR activation on affective state. This review focuses on sex differences in DYN and KOR systems and how these might contribute to sex differences in addictive behavior. Much of what is known about how biological sex influences KOR systems is from research on pain systems. The basic molecular and genetic mechanisms that have been discovered to underlie sex differences in KOR function in pain systems may apply to sex differences in KOR function in reward systems. Our goals are to discuss the current state of knowledge on how biological sex contributes to KOR function in the context of pain, mood, and addiction and to explore potential mechanisms for sex differences in KOR function. We will highlight evidence that the function of DYN-KOR systems is influenced in a sex-dependent manner by: polymorphisms in the prodynorphin (pDYN) gene, genetic linkage with the melanocortin-1 receptor (MC1R), heterodimerization of KORs and mu opioid receptors (MORs), and gonadal hormones. Finally, we identify several gaps in our understanding of "if" and "how" DYN and KORs modulate addictive behavior in a sex-dependent manner. Future work may address these gaps by building on the mechanistic studies outlined in this review. Ultimately this will enable the development of novel and effective addiction treatments tailored to either males or females.

Keywords: female, depression, drug withdrawal, antinociception, estrogens, dopamine, analgesia

There is increasing evidence in humans and laboratory animals for biologically-based sex differences in every phase of drug addiction: acute reinforcing effects, transition from occasional to compulsive use, withdrawal-associated negative affective states, craving, and relapse (Griffin et al., 1989; McKay et al., 1996; Lynch and Taylor, 2004; Lynch, 2006; Fox and Sinha, 2009; Greenfield et al., 2010). In general, as an individual moves from impulsive to compulsive 
drug use, it is thought that a shift occurs such that negative reinforcement dominates over positive reinforcement as the driving force for motivated behavior (Koob, 2008). Although the qualities and magnitude of drug withdrawal syndromes vary among different class of drugs, withdrawal exacerbates reward deficits that contribute to negative reinforcement and contributes to drug craving and relapse (Kenny, 2007; Koob and Le Moal, 2008). Furthermore, repeated drug exposure produces long-lasting neural adaptations that sensitize the organism to drugs and drug-associated cues. Thus, in humans, motivational focus narrows to drug seeking at the expense of natural reward seeking. Consistent with negative reinforcement mechanisms of addiction, one consistent finding in human studies is that drug-dependent women express greater negative emotional states such as stress and depression (Griffin et al., 1989), and these are more likely to trigger craving and relapse in women than men (McKay et al., 1996; Fox and Sinha, 2009). The predominance of comorbid mood disorders in female drug addicts likely arises from preexisting psychopathologies. In the population as a whole, women are twice as likely as men to suffer from anxiety and depression (Kessler, 2003). Although women are more likely to seek treatment, they experience longer episodes of depression and lower rates of recovery (Weissman and Olfson, 1995). Thus, sex differences in stress and reward pathways may explain why women are more vulnerable than men to the negative consequences of drug dependence (Becker et al., 2012). Paradoxically, the prevalence of drug dependence is generally reported to be higher in adult men compared to women (Carroll et al., 2004). Interestingly, more recent epidemiological studies indicate a narrowing in this gender gap (Substance Abuse and Mental Health Services Administration, 2014)-particularly in adolescents. This may reflect changing sociocultural patterns, rather than biology.

Chronic exposure to drugs of abuse elicits neuroadaptations in stress and reward pathways, including enhanced synthesis and release of dynorphin (DYN) - an endogenous ligand at kappa opioid receptors (KORs; Chavkin et al., 1982). Several studies have shown that psychostimulant-induced increases in DYN signaling are coincident with the emergence of depressive-like effects including anhedonia and anxiety (Hurd and Herkenham, 1993; Cole et al., 1995; Shippenberg et al., 2007). However, relatively little is known about the role of DYN and KORs in motivated behavior or drug withdrawalinduced negative affective states in females. Recent work from our lab shows that female rats are less sensitive than males to the depressive-like effects of a KOR agonist (Russell et al., 2014) raising the possibility that the contribution of KORs to negative reinforcement processes differs between the sexes. The purpose of this review is to discuss the current state of knowledge on the regulation and role of DYN and KORs within neural circuits important for emotional processing, with particular emphasis on putative mechanistic underpinnings of these sex differences. Given the nascent state of this field, we will also discuss more established data on sex differences in the role of KORs in nociception with the goal of identifying overlapping mechanisms as well as gaps in our knowledge.

\section{DYNORPHIN AND KAPPA OPIOID RECEPTORS (KORs)}

Dynorphins are a class of opioid peptides that arise from the precursor protein prodynorphin (pDYN) and act as endogenous ligands at the KOR (Chavkin and Goldstein, 1981). DYN and KORs are found throughout the central and peripheral nervous system (Mansour et al., 1988, 1995; Le Merrer et al., 2009), where they modulate a diverse set of physiological outputs including nociception, hypothermia, and water diuresis (Vonvoigtlander et al., 1983), as well as motivated behavior and affective states (Bruchas et al., 2010; Knoll and Carlezon, 2010). Protease cleavage of pDYN during processing releases multiple active peptides selective for the KOR including DYN $A_{1-8} \& 1-17$, DYN B, and $\alpha / \beta$-neoendorphins (Chavkin, 2013). The human pDYN gene contains four exons: exons 1 and 2 encode the $5^{\prime}$ untranslated region (UTR), exon 3 encodes a signal peptide, and exon 4 encodes the DYN peptides (Horikawa et al., 1983). The pDYN gene contains a non-canonical activating protein 1 (AP-1)-Iike site in its promoter region, which is a target for Fos/Jun trans-activation. In addition, the pDYN promoter has been shown to contain three cAMP response elements (CRE) elements, which are targets for CRE binding protein (CREB)mediated transcriptional activation (Douglass et al., 1989, 1994; Cole et al., 1995).

Dynorphins are contained in large dense core vesicles and primarily released in a calcium-dependent manner (Chavkin et al., 1983). They can be released from nerve terminals to cause presynaptic autoinhibition or from dendrites to cause retrograde inhibition of afferents (for review, see Simmons and Chavkin, 1996). Activation of KORs leads to a variety of effects on intracellular signaling pathways, including decreased cAMP production, increased $\mathrm{K}^{+}$and decreased $\mathrm{Ca}^{2+}$ channel conductance, and activation of extracellular signal-regulated kinase (ERK) pathways (Grudt and Williams, 1995; Law et al., 2000; Bruchas et al., 2008; Potter et al., 2011). After sustained KOR activation, receptor desensitization can occur in which G-protein coupled receptor kinase 3 (GRK3) phosphorylates the KOR at serine 369 (KOR-P) (Liu-Chen, 2004). This initiates arrestin-dependent receptor internalization and creates a receptor-protein complex that recruits additional second messenger signaling systems (Bruchas and Chavkin, 2010).

There is evidence in adults that gonadal hormones can regulate the expression and release of dynorphins in spinal cord, hypothalamic nuclei and in hippocampus (Gintzler et al., 2008; Gottsch et al., 2009; Torres-Reveron et al., 2009). These effects have not yet been tested for a connection to drug reward and addictive behavior. To date, the little information available on sex differences in KOR systems comes primarily from studies on KOR-mediated antinociception (Rasakham and Liu-Chen, 2011).

\section{INFLUENCE OF SEX ON BRAIN AND BEHAVIOR}

Sex differences in behavior can be classified into three main types (McCarthy and Arnold, 2011). First, behavioral endpoints can exist in either "male" or "female" forms or be present in one sex 
and absent in the other. Since both men and women can become addicted to drugs, there is not an absolute sexual dimorphism in addiction per se. However, it is possible that drugs of abuse produce a specific behavioral or neurochemical outcome in only one sex. Second, behavioral endpoints can exist on a spectrum in which the average behavior is different in males and females (e.g., pain thresholds and analgesic efficacy of opioid painkillers). This is the most commonly observed type of sex difference in drug addiction research. A challenge for neuroscientists is ascertaining whether such differences are socially or biologically based. Third, behavioral endpoints can be the same in males and females, but the underlying neural mechanisms that produce the behavior can be different (e.g., certain stress responses). This type of sex difference often goes undetected or unreported, since there are no overt behavioral differences between males and females. But sex differences in the mechanisms that lead to addictive behavior could profoundly influence the way in which addiction is treated.

The $\mathrm{X}$ and $\mathrm{Y}$ sex chromosomes are the origin of all biological sex differences (McCarthy and Arnold, 2011). Expression of the Y-linked gene, Sry, leads to testes development in males, which subsequently secrete testosterone (Goodfellow and LovellBadge, 1993; Becker et al., 2005). In the absence of Sry, ovaries develop, which secrete estrogen and progesterone. The timing and mechanisms by which the sex chromosomes influence sexual dimorphism vary in three primary ways. First, there are direct effects of genes expressed on $\mathrm{X}$ and $\mathrm{Y}$ chromosomes on brain and somatic tissues. This can be through unique gene expression or sex-dependent expression levels of the same genes. For example, Sry is expressed in midbrain dopamine-containing cells and has direct male-specific effects (Dewing et al., 2006). The gene Xist is expressed from one of the two X chromosomes in nongermline cells in females and is responsible for inactivation of that chromosome, thus insuring that gene expression between males and females is fairly consistent. However, some genes escape $\mathrm{X}$ inactivation in a tissue-specific manner. For example, pDYN gene expression is higher in the striatum of $\mathrm{XX}$ mice, independent of gonadal hormones, suggesting that inactivation is incomplete, at least in this brain region (Chen et al., 2009). The second way that sex chromosomes influence sexual dimorphism is through organizational effects of gonadal hormones during fetal and neonatal periods. The effects of circulating gonadal hormones on brain development in humans are greatest during weeks 8 through 24 of gestation (McCarthy, 2010). During this critical period, neural structures are still being established in the fetus. At this time, male fetuses secrete over 2.5 times more testosterone than females (Auyeung et al., 2013). In males, circulating testosterone is aromatized to estradiol in the central nervous system. There it masculinizes and defeminizes the brain, modulating synapses and shaping the formation of brain regions (McCarthy and Arnold, 2011). For example, organizational processes sexualize brain structures such as the preoptic area and the suprachiasmatic nucleus of the hypothalamus, the basolateral amygdala (BLA), the bed nucleus of the stria terminalis (BNST), and the corpus callosum (Collaer and Hines, 1995). Of particular importance to addiction and mood disorders are the amygdala and the BNST (Bruchas et al., 2010; Knoll and Carlezon,
2010). Third, there are activational effects of circulating gonadal hormones during and after puberty (McCarthy et al., 2012) Fluctuations in hormone secretion may affect behaviors on a short-term scale, but are quickly mitigated after steroid concentrations return to baseline(McCarthy et al., 2012).

The steroid hormones testosterone, estrogen, and progesterone activate androgen (AR), estrogen $\alpha$ and $\beta$ (ER $\alpha$ and $\operatorname{ER} \beta$ ), and progesterone (PR) receptors, respectively. These act primarily as nuclear transcription factor receptors capable of directly interacting with DNA at specific response elements and modulating gene transcription (Beato, 1989). It is also clear, from more recent research, that steroid hormones act rapidly on membrane bound receptors to activate signal transduction pathways with broad effects on cellular physiology (Balthazart and Ball, 2006). Indeed, a new membrane-bound G proteincoupled estrogen receptor (GPER-1/GPR30) has been identified (Revankar et al., 2005) and implicated in the non-genomic effects of estrogen (Elkabes and Nicot, 2014). Both males and females can produce testosterone and estrogen, although the divergent effects of these steroid hormones are mediated by sex differences in their levels, distribution and metabolism, as well as the levels and distribution of their cognate receptors (McCarthy and Arnold, 2011). Although there are many hormone-sensitive areas of the brain, of particular importance to drug addiction is the presence of steroid hormone receptors within neural circuits associated with mood regulation and stress sensitivity, such as the mesocorticolimbic system, the extended amygdala, and the hypothalamic pituitary adrenal (HPA) axis (see Figure 1). As such, it is likely that both organizational and activational effects of gonadal hormones within these neural circuits contribute to sex differences in motivated behavior and affective states.

\section{ROLE OF KOR SYSTEMS IN PAIN}

\section{Human}

Sex differences have been reported in the perception of pain (Gear et al., 1996; Fillingim, 2000; Sibille et al., 2011) and in the efficacy of opioid analgesics to ameliorate pain (Fillingim et al., 2004; Zacny and Beckman, 2004; Bodnar and Kest, 2010; Rasakham and Liu-Chen, 2011). In general, women tend to demonstrate lower pain thresholds, less pain tolerance and higher evoked pain intensity (Gear et al., 1996; Riley et al., 1998; Sibille et al., 2011) as well as report higher pain ratings (Zacny and Beckman, 2004). However, there is significant variability between and within studies, the effect sizes are often very small, and sex differences only exist for some types of pain measures (Berkley, 1997; Wiesenfeld-Hallin, 2005).

Similar to MOR agonists such as endorphins and morphine, DYN and exogenous KOR agonists have antinociceptive properties (Han and Xie, 1982, 1984) but with a much lower abuse potential (Fraser and Rosenberg, 1964). Just as sex differences in the perception of pain are complex, the analgesic effects of opioids in men and women depend on the specific type of pain and the opioid analgesic. Mixed KOR/MOR partial agonists including pentazocine, nalbuphine, and butorphanol have been shown to produce greater analgesia in women 

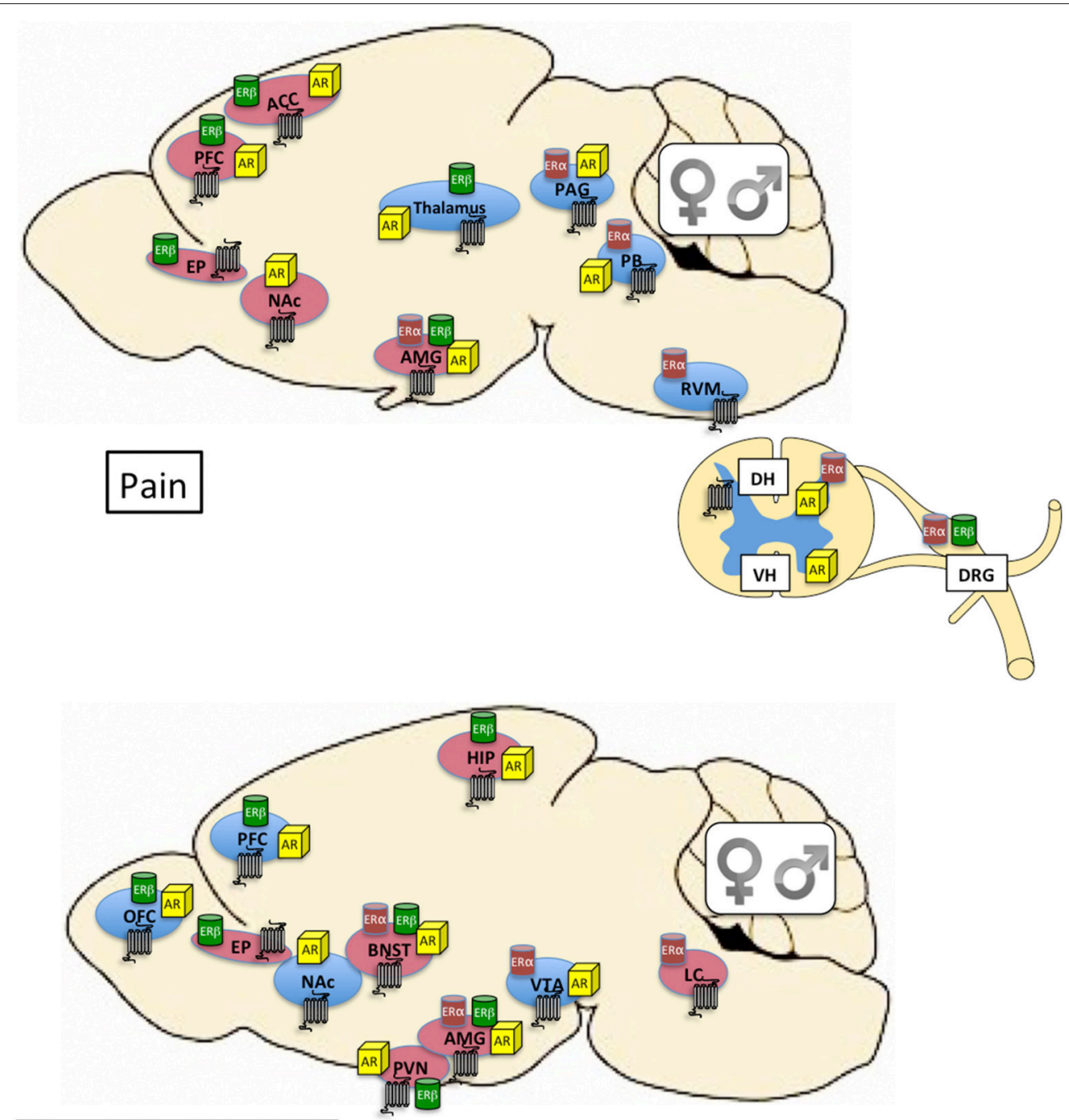

Reward and affect

FIGURE 1 | Top: Distribution of kappa opioid (7-transmembrane receptor), estrogen, and androgen receptors within neural circuits involved in pain. Brain regions shaded in blue are primarily associated with sensory dimensions of pain whereas those shaded in red are primarily associated with affective dimensions of pain. There is crosstalk between the various brain regions (see Cahill et al., 2014 for review). Bottom: Distribution of kappa opioid, estrogen, and androgen receptors within neural circuits involved in affective state and motivated behavior. Brain regions shaded in blue are primarily associated with the mesocorticolimbic dopamine system and reward processing. Brain regions shaded in red are primarily associated with stress and anxiety (negative affective states). Expression of KORs, ERs, and ARs is qualitatively similar between males and females. The final impact of KOR activation on neuronal function and behavior depends on the cellular localization of the receptor (e.g., pre- or post-synaptic) and the projection target of the KOR-expressing neuron. Currently this level of detail is relatively unexplored in male vs. female brain. Receptor expression in this figure is based on evidence of overlapping mRNA expression and receptor binding: indicated brain regions are thought to synthesize and express the indicated receptors (Morris and Herz, 1987; Mansour et al., 1988, 1995; Besse et al., 1990; Simerly et al., 1990; Arvidsson et al., 1995; Lumbroso et al., 1996; Shughrue et al., 1997; Laflamme et al., 1998; Slowe et al., 1999; Papka et al., 2001; Hamson et al., 2004; Harris et al., 2004; Vanderhorst et al., 2005; Loyd and Murphy, 2008; Le Merrer et al., 2009; Feng et al., 2010; Rasakham and Liu-Chen, 2011). ACC, anterior cingulate cortex; AMG, amygdala; AR, androgen receptor; BNST, bed nucleus of the stria terminalis; DH, dorsal horn of spinal cord; DRG, dorsal root ganglia; EP, endopiriform cortex; ER, estrogen receptor; HIP, hippocampus; LC, locus coeruleus; NAc, nucleus accumbens; OFC, orbitofrontal cortex; PAG, periaqueductal gray; PB, parabrachial nucleus; PFC, prefrontal cortex; PVN, paraventricular nucleus of the hypothalamus; RVM, rostral ventral medulla; VH, ventral horn of the spinal cord; VTA, ventral tegmental area.

compared to men in post-operative dental surgery (Gear et al., 1996, 1999). Similarly, the analgesic effect of pentazocine has been shown to be more robust in women for ischemic and thermal pain (Mogil et al., 2003). In contrast, Fillingim et al. (2004) reported no sex differences in the analgesic effects of pentazocine in models of heat, ischemic and pressure pain. There are also numerous examples in which opioid analgesics have greater effects in men. The partial MOR/KOR agonist butorphanol produces higher analgesic ratings in men in the cold-water stimulus pain assay (Zacny and Beckman, 2004), 
although other studies suggest no sex differences in the analgesic effects of either the MOR agonist morphine or butorphanol (Sibille et al., 2011). Importantly, clearance of butorphanol has been shown to be lower in women compared to men, raising the possibility that pharmacokinetic differences between men and women are a factor and should be considered in dose determinations (Shyu et al., 1994). Taken together, it is almost impossible to draw sweeping conclusions about how sex impacts pain and analgesia. Rather, the findings to date highlight the importance of studying each facet of analgesia in both men and women and suggest that genetic variability plays a major role.

\section{Animals}

According to a recent analysis, approximately $80 \%$ of the animals studies published in the journal "Pain" in the last decade have been done in males and only $4 \%$ of those studies were designed to test pain perception in both sexes (Bodnar and Kest, 2010). Animal studies examining sex differences in pain or analgesic sensitivity have revealed that the presence and direction of sex differences are dependent on the strain chosen for study (Mogil et al., 2000). The interactions between sex and genetics on pain response are still relatively unexplored, but identification of relevant genes should facilitate development of more effective analgesics for both men and women.

Interestingly, animal studies tend to demonstrate more robust analgesic effects of KOR ligands in males compared to females, whereas the opposite is generally true in human studies (see Rasakham and Liu-Chen, 2011). For example, the selective KOR agonist U50,488 has more robust analgesic effects in male rats and mice compared to females in the tail flick assay (Kavaliers and Innes, 1987; Barrett et al., 2002; Mogil et al., 2003; Sternberg et al., 2004a; Stoffel et al., 2005), although this does not hold for every strain (Rasakham and Liu-Chen, 2011). Reproductive hormones such as testosterone and estradiol do not seem to significantly modulate sensitivity to the analgesic effects of opioids under many-but not all-conditions (Stoffel et al., 2005). The sex differences in the antinociceptive effects of KOR agonists have been suggested to be primarily spinal rather than supraspinal dependent (Craft and Bernal, 2001).

\section{Neuroanatomy of KORs Related to Pain}

DYN and KORs in the peripheral and central nervous system play major roles in the sensory and affective components of pain (Cahill et al., 2014). As such, the neural circuits sub serving pain and affect are at least partially overlapping (see Figure 1). Chronic pain stimuli lead to sustained DYN release in the spinal cord, which is thought to be a compensatory analgesic response (Iadarola et al., 1988; Cahill et al., 2014). Thus, it is thought that analgesic effects of KOR activation are due in part to DYN and KOR localization in the spinal cord and brain stem, where they act to inhibit pain pathways (Millan et al., 1989; Watkins et al., 1992; Simonin et al., 1995; Yaksh, 1997; Cahill et al., 2014). In the spinal cord, KORs are localized pre- and post-synaptically (Ji et al., 1995): a proportion are expressed in the superficial dorsal horn of the spinal cord (Gouardères et al., 1986; Maekawa et al., 1994; Mansour et al., 1994b, 1996; Arvidsson et al., 1995) and a proportion $(\sim 50 \%)$ on sensory afferents from the dorsal root ganglion (Besse et al., 1990; Maekawa et al., 1994; Mansour et al., 1994b, 1996; Arvidsson et al., 1995). KORs are also co-expressed with other opioid receptors (mu and delta) on primary sensory neurons. In rat and rabbit, the highest levels of DYN immunoreactivity have been observed in the dorsal part of the spinal cord, and the lowest levels in the dorsal root ganglia (Botticelli et al., 1981). KOR agonists have been shown to modulate excitatory transmission in substantia gelatinosa neurons of the rat spinal cord via inhibition of AMPA-mediated neurotransmission (Randic et al., 1995).

In addition to spinal actions of DYN (Han and Xie, 1982), there is evidence supporting analgesic KOR effects at supraspinal sites (Cahill et al., 2014) including parietal cortex and amygdala (Abraham et al., 2000; Narita et al., 2006). The rostral ventromedial medulla (RVM) has also been shown to be a crucial site for the supraspinal antinociceptive actions of opioids. In particular, the nucleus raphe magnus forms a component of a descending inhibitory network that modulates nociceptive neurotransmission at the level of the spinal cord dorsal horn (Marinelli et al., 2002). This nucleus projects to the spinal cord and approximately $20 \%$ of the neurons respond to KOR ligands (Marinelli et al., 2002). Pain transmission pathways from the periphery to the CNS involve projections from the medulla to the midbrain and more anterior structures (Al-Hasani and Bruchas, 2011), which overlap with structures involved in KOR effects on affective state (see Figure 1).

\section{ROLE OF KOR SYSTEMS IN AFFECTIVE STATE}

\section{Human}

Based on the hypothesis that KOR agonists could be utilized as non-addictive analgesics, a major effort was initiated to develop and test KOR-selective ligands in pain models. However, patients (only males were included in these early studies) reported aversive and depressive signs (including dysphoria) after treatment with non-selective KOR agonists such as cyclazocine, spiradoline, and the more selective KOR agonist MR2033 (Pfeiffer et al., 1986; Chappell et al., 1993). Interestingly, pentazocine, a relatively specific KOR partial agonist/MOR antagonist (Zhu et al., 1997) is still used for obstetrical pain, perhaps because females are less sensitive to the aversive effects of KOR activation (Russell et al., 2014). Indeed, a case report describes antidepressant effects of the naturally occurring hallucinogen Salvia divinorum, a rare member of the mint family in which the active ingredient is the highly selective and potent KOR agonist, salvinorin $\mathrm{A}$, in a woman with intractable depression (Hanes, 2001). In contrast to this, a retrospective survey of recreational Salvia users reported similar levels of drug-induced anxiety in men and women (Gonzalez et al., 2006). Given the negative effects of KOR agonists on mood, drug development efforts for KOR ligands as analgesics were largely halted. However, the information gleaned from these studies has been instrumental in our understanding of the role of DYN/KORs in affective state and has led to novel hypotheses 
about the clinical utility of KOR-selective compounds (Carlezon et al., 2009).

One such hypothesis is that KOR-mediated reductions in hyperdopaminergia may reduce symptoms of mania in people with bipolar disorder. This was tested using pentazocine in a small open-label study in 10 patients ( 7 male and 3 female) with mania. Pentazocine reduced manic symptoms transiently but substantially and significantly in each subject without causing notable sedation or affecting psychotic symptoms (Cohen and Murphy, 2008).

A second hypothesis that has gained traction is that KOR antagonists may reduce depressive-like symptoms that characterize numerous psychiatric disorders including major depressive disorder (MDD), post-traumatic stress disorder (PTSD), and drug addiction. In support of this, buprenorphine, a partial MOR agonist/ KOR antagonist, has been shown to have antidepressant efficacy in MDD in observational studies (Emrich et al., 1982; Walsh et al., 1994, 1995; Bodkin et al., 1995; Cowan, 2003; Nyhuis et al., 2008; Karp et al., 2014) and to reduce depressive symptoms in heroin addicted patients who were depressed at intake (Kosten et al., 1990). Amazingly, these studies were conducted only in males or, when females were included, no information is provided on the contribution of gender to the results. More recently, attempts have been made to isolate the KOR antagonist properties of buprenorphine by co-administering MOR antagonists. Rothman and colleagues hypothesized that a KOR antagonist would alleviate dysphoria observed in the protracted opiate withdrawal syndrome and as such reduce rates of relapse in abstinent opioid-dependent patients. A combination of buprenorphine and the MOR antagonist naltrexone has been shown to produce a substantial reduction in cocaine and opiate use (Rothman et al., 2000; Gerra et al., 2006). Perhaps the most compelling clinical data supporting antidepressant effects of KOR antagonists come from a recent study in which a combination of buprenorphine and the potent MOR antagonist samidorphan administered to subjects with treatment resistant MDD resulted in significant and substantial antidepressant activity without addictive potential (Ehrich et al., 2015).

At this point there is little conclusive evidence regarding sex differences in the direct role of DYN and KOR systems in drug addiction in humans. However, there is increasing evidence for sex differences in the role of KORs in mediating stress responses and affective states in preclinical animal models, which may help us understand, on a mechanistic level, why addiction is experienced differently in men and women.

\section{Animals}

In males, activation of KORs produces depressive-like and anxiogenic behaviors (Bals-Kubik et al., 1989; Todtenkopf et al., 2004; Carlezon et al., 2006; Tomasiewicz et al., 2008; Ebner et al., 2010; Knoll et al., 2011; Muschamp et al., 2011), encodes the dysphoric component of stress (Land et al., 2008; Bruchas et al., 2010), and can promote drug-seeking behavior (Negus, 2004; McLaughlin et al., 2006; Redila and Chavkin, 2008; Schindler et al., 2010). Likewise, KOR blockade has antidepressant and anxiolytic effects (Pliakas et al., 2001; Newton et al., 2002; Mague et al., 2003; Knoll et al., 2007), attenuates aversive states associated with cocaine withdrawal (Chartoff et al., 2012), and attenuates drug-seeking behavior (Beardsley et al., 2005; Carey et al., 2007; Walker and Koob, 2007; Redila and Chavkin, 2008; Land et al., 2009; Wee et al., 2009; Bruchas et al., 2010). These findings are consistent with observations that KOR agonists produce dysphoric and depressive-like states in men (Pfeiffer et al., 1986).

We recently demonstrated that female rats are less sensitive than males to the depressive-like effects of the KOR agonist U50,488 (Russell et al., 2014) using intracranial self-stimulation (ICSS), an operant behavior that is sensitive to increases and decreases in reward function (Carlezon and Chartoff, 2007). This effect is independent of circulating gonadal hormones, as gonadectomy did not alter responses to U50,488 (Russell et al., 2014). Cellular mapping showed U50,488-induced cFos activation to be greater in corticotropin releasing factor (CRF)-containing neurons of the paraventricular nucleus of the hypothalamus (PVN) and in non-CRF-containing neurons of the BNST oval nucleus in females compared to males (Russell et al., 2014). In an earlier study, it was shown that female rats take significantly longer than males to discriminate the KOR agonist U69,593 from vehicle using an FR-10 schedule of food reinforcement (Craft et al., 1998). The ED50 for U69,593 discrimination was significantly higher in females, and the peak and offset for U69,593 occurred earlier in females compare to the males (Craft et al., 1998). In contrast, Robles et al. (2014) demonstrated in the California mouse that females formed conditioned place aversions to a low, but place preferences to a high, dose of U50,488. However, males were insensitive to the low and formed conditioned place aversions to the high dose of U50,488. Together these findings highlight how species and behavioral paradigm play a major role in the function of KORs.

In males, co-administration of KOR agonists with cocaine has been shown to prevent the development of locomotor sensitization to cocaine as well as cocaine-induced conditioned place preferences (Heidbreder et al., 1995; Shippenberg and Rea, 1997). However, there is emerging evidence that prolonged or prior exposure to KOR agonists can potentiate the effects of cocaine. For example, exposure to KOR agonists can increase the locomotor stimulant effects of psychostimulants as well as stimulated dopamine release in striatal regions, depending on the timing and context of KOR agonist exposure (Heidbreder et al., 1998; Fuentealba et al., 2006, 2007; Chartoff et al., 2008). Continuous treatment of rhesus monkeys with the KOR agonist U50,488 increases cocaine choice (Negus, 2004), suggesting a KOR-mediated increase in the relative reinforcing effects of cocaine. Pretreatment with KOR agonists can potentiate cocaineinduced place preferences (McLaughlin et al., 2006) and brain stimulation reward (Chartoff et al., 2015), and activation of KORs can reinstate cocaine seeking (Redila and Chavkin, 2008). One explanation for KOR-mediated potentiation of cocaine reward that has been proposed (McLaughlin et al., 2006) is that activation of KORs prior to administration of cocaine produces a dysphoric state that enhances the rewarding properties of cocaine. This 
raises the possibility that, in females, KOR activation would fail to potentiate reward-related effects of drugs of abuse. This has yet to be directly tested.

Consistent with idea that KOR activation can enhance psychostimulant effects in males but not females, it has been reported that pretreatment with the non-selective KOR agonist spiradoline potentiates acute cocaine-induced locomotor activity in male, but not female, mice (Sershen et al., 1998). Further in vitro analyses indicated that the ability of spiradoline to inhibit NMDA-evoked dopamine release in striatal slices was lower in female compared to male tissue (Sershen et al., 1998). This is consistent with the general concept that the net change (delta) in dopamine signaling determines behavioral responses to cocaine (Ehrich et al., 2014; Chartoff et al., 2015). In guinea pigs, which have KOR expression levels and distributions quite similar to humans, the effects of the KOR agonist U50,488 on basal measures of body posture and analgesia were shown to be consistently lower in females compared to males (Wang et al., 2011). KOR effects on basal locomotor activity did not differ between males and females, whereas acute cocaine-induced locomotor activity was substantially higher in females compared to males. In the same study, U50,488 produced greater decreases in cocaine-induced locomotor activity in female guinea pigs compared to males-bringing activity down to levels observed in males treated with cocaine alone (Wang et al., 2011). Although it's difficult to reconcile the findings described above, with one study reporting KOR-mediated increases in cocaine effects (Sershen et al., 1998) and the other study reporting KORmediated decreases (Wang et al., 2011), the studies highlight the importance of species, drug, and experimental design in modulating KOR effects. Furthermore, these studies touch upon the important interactions of KORs with the mesolimbic dopamine system and are broadly consistent with studies showing greater evoked dopamine release in female compared to male nucleus accumbens (Walker et al., 2000). It is possible that enhanced dopamine function can protect females from the inhibitory effects of KOR activation.

\section{Neuroanatomy of KORs Related to Affective State}

In mammals, KORs are expressed throughout brain regions involved in affect, cognition, and motivated behavior, including the ventral tegmental area (VTA), nucleus accumbens (NAc), prefrontal cortex (PfC), hippocampus, dorsal striatum, amygdala, BNST, locus coeruleus, substantia nigra, dorsal raphe nucleus, pedunculpontine nucleus, and hypothalamus (Mansour et al., 1994a,b, 1995, 1996; Peckys and Landwehrmeyer, 1999; Svingos et al., 1999; Margolis et al., 2003; Le Merrer et al., 2009). The effect of KOR activation on neural transmission depends on the phenotype (e.g., excitatory or inhibitory) of the neuron expressing KORs, its projection target, and whether the receptor is expressed pre- or post-synaptically. These criteria have been elegantly described for KOR-mediated modulation of VTA dopamine neurotransmission. Broadly, KOR activation inhibits dopamine release (Margolis et al., 2003, 2005, 2006). The VTA sends dopaminergic efferents to many brain regions including the NAc, PfC, and basolateral amygdala. VTA dopamine neurons express KOR mRNA and the final protein expression patterns appear to depend on projection target (Ford et al., 2006; Margolis et al., 2006). Based on retrograde tracing from VTA target sites and electrophysiological recordings of VTA dopamine neurons (Margolis et al., 2006), it has been demonstrated that VTA neurons that project to the NAc express KORs predominantly on their nerve terminals within the NAc. In contrast, VTA dopamine neurons that project to the PfC express KORs predominantly on their cell bodies within the VTA. Consistent with this, administration of KOR agonists into the NAc decreases local dopamine concentrations (Donzanti et al., 1992; Spanagel et al., 1992), most likely by stimulating presynaptic KORs on dopaminergic afferents from VTA neurons (Svingos et al., 1999). In a separate study using similar techniques (Ford et al., 2006), it was shown that KOR activation inhibits VTA dopamine neurons projecting to the NAc but has little effect on dopamine neurons projecting to the basolateral amygdala. Furthermore, KOR activation selectively inhibits somatodendritic dopamine release (via KORs expressed on dopamine neuron cell bodies) in NAc projection neurons. DYN can modulate VTA dopaminergic neurons via actions on non-dopamine neurons as well. For example, KORs are likely expressed on GABAergic (Ford et al., 2006; Graziane et al., 2013; Crowley and Kash, 2015) and glutamatergic (Margolis et al., 2005) neurons that synapse on dopamine neurons in the VTA. Indeed, DYN has been shown to inhibit glutamate transmission in the VTA (Mu et al., 2011). The origin of DYN inputs to the VTA is not fully understood, but comes in part from the nucleus accumbens and lateral hypothalamic neurons that co-express orexin (Muschamp et al., 2014).

KORs and DYN are also enriched in the basolateral amygdala, the central nucleus of amygdala, and the BNST (Crowley and Kash, 2015). In the central nucleus of amygdala, pDYN mRNA is expressed in at least some CRF-expressing neurons (Marchant et al., 2007). The highest concentration of KOR binding in the rodent is found in the endopiriform cortex (Le Merrer et al., 2009). The endopiriform cortex is relatively understudied but appears to be an area of convergence for sensory and affect-related information and is involved in aspects of the storage, consolidation, and retrieval of emotional memories (de Curtis and Paré, 2004). In the guinea pig endopiriform cortex, KOR levels are higher in males compared to females (Wang et al., 2011), but the functional significance of this is unkown.

In the hippocampus, DYN is localized in dentate gyrus granule cells, from which it is locally released to act as a retrograde transmitter inhibiting excitatory inputs within the hippocampus (Drake et al., 1994). The dentate gyrus granule cells form the mossy fiber pathway that is involved in learning related to drug abuse (Torres-Reveron et al., 2009). DYN and ER $\beta$, but not ER $\alpha$, are colocalized in the mossy fiber pathway. Female rats in estrus have been shown to have increased DYN levels in the dentate gyrus and certain CA3 lamina compared to rats in proestrus or diestrus (Torres-Reveron et al., 2009). Also, U50,488-stimulated $\left[{ }^{35} \mathrm{~S}\right] \mathrm{GTP} \gamma \mathrm{S}$ binding in the dentate gyrus of guinea pigs has been shown to be higher in females compared to males (Wang et al., 2011). 


\section{MECHANISMS UNDERLYING SEX DIFFERENCES IN DYN/KOR FUNCTION}

\section{Polymorphisms in the Prodynorphin Gene}

Both environmental and genetic factors significantly increase vulnerability to drug addiction (Tsuang et al., 1996; Clarke et al., 2012). Most genetic variation in humans is attributable to single nucleotide polymorphisms (SNPs). These are positions on a DNA sequence at which two alternative bases occur in at least $1 \%$ of the human population (Wang et al., 1998). The remaining genetic variation in humans is due to insertions or deletions of one or more nucleotides in genes, repeat length polymorphisms and DNA rearrangements (Sachidanandam et al., 2001). Sex-linked polymorphisms in the pDYN gene have been associated with increased vulnerability to develop drug addiction (Clarke et al., 2009). Specifically, two SNPs, rs1997794 in the promoter and rs 1022563 in the $3^{\prime}$ UTR region of the pDYN gene have been shown to be significantly associated with opioid dependence in women but not men in a Chinese population, suggesting that these SNPs confer an increased risk for women (Clarke et al., 2009). In European Americans, SNPs rs1022563, rs910080, and rs199774 have been shown to be significantly associated with an increased risk for opioid addiction in both men and women. However, the odds ratio was higher in women compared to men (Clarke et al., 2012). In contrast, no significant associations with SNPs in the pDYN gene have been found in African Americans (Clarke et al., 2012). SNPs in the 3' UTR of the pDYN gene (rs910080 and rs2235749) have been associated with decreased pDYN expression (Yuferov et al., 2009). This raises the possibility that DYN is decreased in women with pDYN SNPs that are associated with increased risk of developing opioid dependence. Future studies should determine why the association of these SNPs with opioid dependence is higher in women and also whether their presence can predict an increased risk of developing opioid use disorders in specific subpopulations of women.

\section{Sex-Linked Modulation of KOR Analgesia by the Melanocortin-1 Receptor (MC1R) in Females vs. the NMDA Receptor in Males}

One of the most well characterized sex-linked mechanisms in KOR-mediated opioid analgesia is the selective involvement of $\mathrm{N}$-methyl-D-aspartate receptors (NMDARs) in males vs. that of melanocortin-1 receptors (MC1Rs) in females (Mogil and Bailey, 2010). NMDAR antagonists can block stress- and KORinduced analgesia in males but not females (Mogil et al., 1993; Kavaliers and Galea, 1995; Kavaliers and Choleris, 1997; Mogil and Belknap, 1997). In contrast, MC1Rs are necessary for KORmediated analgesia in females but not males (Mogil and Bailey, 2010). These differences are hormonally dependent since chronic estrogen and acute progesterone have been shown to act as a "switch": female mice utilize the MC1R system under normal conditions or after hormone replacement following gonadectomy but switch to the NMDAR system following gonadectomy or estropause (a state of reproductive senescence; Sternberg et al., 2004a,b).
Using Quantitative Trait Locus (QTL) mapping, Mogil and colleagues demonstrated that a region of distal mouse chromosome 8 that contains the MC1R gene is linked with stress-induced analgesia in female, but not male mice. QTL mapping is a technique in which the coinheritance of continuous traits and polymorphic DNA markers such as microsatellite markers or SNPs are used in order to identify the chromosomal location of genes that are responsible for trait variability (Lander and Schork, 1994; Mogil et al., 2003). Specifically, Mogil and colleagues measured U50,488-induced analgesia in mice and then genotyped them for three microsatellite markers spanning a 24-cM region on distal chromosome 8 . They demonstrated a significant linkage between genotype and U50,488-induced analgesia in females, but not males. The QTL accounted for $25 \%$ of overall trait variance (Mogil et al., 2003). Female mice inheriting two copies of an allele at microsatellite marker D8Mit56 inherited from the DBA/2J background mouse strain, which is particularly sensitive to the analgesic effects of opioids (Belknap et al., 1990) displayed twice as much U50,488-induced analgesia compared to female mice inheriting two copies of an allele inherited from the C57/6J background mouse strain. The allelic status of male mice at this marker had no consequence (Mogil et al., 2003).

In humans, MC1R switches melanin synthesis from the red/yellow phaeomelanin pathway to the black eumelanin pathway in both skin and hair (Sturm et al., 2001). Individuals with red hair are homozygotes or compound heterozygotes at major MC1R variants (R151C, R160W, D294H), which are associated with loss of function and reduced cAMP production (Bastiaens et al., 2001) upon receptor activation with $\alpha$ melanocyte stimulating hormone ( $\alpha-\mathrm{MSH})$, an endogenous ligand at MC1Rs. Women with variants of the MC1R gene that are associated with red hair and fair skin (i.e., loss of function variants) have been shown to display significantly greater pentazocine-mediated analgesia than men with the same variants (Mogil et al., 2003). Although it is not known how MC1R interacts with KORs in a female-specific manner, both KORs and MC1Rs signal through cAMP pathways (Bastiaens et al., 2001) and are found in the periaqueductal gray (PAG) and locus coeruleus (LC), two brain regions important for sensory and affective dimensions of pain (Caruso et al., 2014). One possible mechanism involves receptor heterodimerization, although this has not been directly tested.

\section{Heterodimerization of MOR and KOR}

Traditionally, GPCRs have been thought to act as monomers, but more recent research suggests that GPCRs may form homo or heterodimers as part of their normal trafficking and function (Prinster et al., 2005). As such, heterodimerization is an important mechanism underlying receptor function (Kern et al., 2012). In some cases heterodimerization may even be required for the surface expression and functionality of a receptor. Even if heterodimerization is not absolutely required, it can still result in dramatic changes in receptor pharmacology (i.e., increase specificity for a ligand), internalization processes (Prinster et al., 2005; Lohse, 2010), and it can stabilize specific 
receptor conformations that promote coupling with discrete downstream effectors (Kern et al., 2012).

One of the mechanisms suggested to underlie sex differences in the antinociceptive effects of opioids is the formation of MOR and KOR heterodimers (Chakrabarti et al., 2010). MOR/KOR heterodimers have been shown to be most prevalent in the spinal cord of proestrous females (cycle stage with highest estrogen levels), followed by females in diestrous and estrous and finally in males (Chakrabarti et al., 2010), suggesting that estrogen contributes to their formation (Figure 2). Consistent with this, spinal synthesis of estrogen and subsequent rapid signaling through membrane-localized ERs regulate MOR/KOR heterodimerization (Liu et al., 2011). Blockade of either ER $\alpha$, ER $\beta$ or progesterone receptor (PR) substantially reduces MOR/KOR heterodimers and shifts morphine-induced antinociception from being KOR-dependent to KOR-independent (Liu et al., 2011). Exogenous or endogenous estrogen enhances KORmediated antinociception in females, whereas testosterone has no effect in males (Lawson et al., 2010). Despite the clear regulation by estrogen, it has also been reported that MOR/KOR heterodimers are more prevalent in ovariectomized females compared to males (Chakrabarti et al., 2010) indicating an additional sex-dependent but estrogen independent mechanism. MOR/KOR heterodimers have been shown to utilize spinal $\mathrm{DYN}_{1-17}$ as a substrate for the female-specific KOR component of spinal morphine antinociception (Chakrabarti et al., 2010).

To date, MOR and KOR heterodimerization has not been described in neural circuits that modulate motivated behavior. The necessary ingredients are present, as there is substantial overlap in MOR and KOR expression in brain regions such as the NAc, BNST, PfC, VTA, and amygdala (Le Merrer et al., 2009). Furthermore, ER $\alpha$ and $\operatorname{ER} \beta$ are also expressed in these regions (Figure 2), which would allow for estrogen-mediated facilitation of MOR/KOR heterodimers, as described above. The functional consequences of putative MOR/KOR heterodimers within reward circuits are not easy to conceptualize, as behavioral effects of MOR and KOR agonists tend to oppose each other. This is different from pain systems, in which both MOR and KOR agonists have analgesic properties. A recent study demonstrated heterodimerization of orexin receptor 1 and KORs in the VTA (Chen et al., 2015), which is consistent with the idea that MOR/KOR heterodimers in similar brain regions are feasible.

\section{Gonadal Hormone Mechanisms of KOR Function}

There is substantial evidence for organizational and activational roles of gonadal hormones in mediating effects of KORs (Forman et al., 1989; Limonta et al., 1989; Mogil et al., 1993; Rasakham and Liu-Chen, 2011), including roles in the processes described above. However, the actual mechanisms through which hormones mediate their effects are not fully understood. It is also important to note that DYN and KOR function can be sexdependent but hormone-independent. For example, it has been shown in the four-core genotype mouse model that XX mice that have either male or female gonads have higher pDYN mRNA expression in the striatum compared to XY mice that have either male or female gonads (Chen et al., 2009). This is likely due to incomplete inactivation of portions of the $\mathrm{X}$ chromosome.

The most straightforward manner in which gonadal steroids might influence KOR function is via transcriptional mechanisms involving steroid hormone receptor binding to estrogen or androgen response elements found in regulatory regions on genes (Gruber et al., 2004; Klinge et al., 2004; Gottsch et al., 2009). As an example, estradiol has been shown to decrease DYN expression in the arcuate nucleus of the hypothalamus in wild-type but not ER $\alpha-/$ - mice through an ERE-dependent pathway (Gottsch et al., 2009). These findings suggest that DYN-expressing neurons in the arcuate play a role in estrogenmediated negative feedback of pulsatile gonadotropin-releasing hormone $(\mathrm{GnRH}) /$ luteinizing hormone $(\mathrm{LH})$ release (Mostari et al., 2013). There is also evidence that testosterone can regulate DYN expression. In castrated Romney Marsh rams it has been shown that testosterone treatment increases pDYN mRNA in the supraoptic nucleus and the BNST during the breeding season (Scott et al., 2008).

A more indirect mechanism for gonadal hormone control of gene expression is through modulation of transcription factor activity. For example, the pDYN gene contains cAMP response element $(\mathrm{CRE})$ sequences in its promoter that bind the transcription factor CREB (Douglass et al., 1994; Cole et al., 1995). Estrogen treatment has been shown to increase CREB phosphorylation in the anteroventral periventricular nucleus, resulting in elevated pCREB in approximately $25 \%$ of pDYNpositive neurons in this region (Gu et al., 1996).

Gonadal hormones can also influence DYN and KOR function through rapid effects at membrane receptors and nontranscriptional effects on second messenger pathways. Pain tolerance is increased during pregnancy (Cogan and Spinnato, 1986), an effect due in part to enhanced KOR-mediated antinociception in the spinal cord (Gupta et al., 2001; Gintzler et al., 2008). This phenomenon of gestational antinociception can be mimicked in gonadectomized rodents by administering pregnancy level concentrations of estrogen and progesterone (Dawson-Basoa and Gintzler, 1998; Gintzler and Liu, 2012). It has been shown that ER $\alpha$ is coexpressed with DYN in the dorsal horn of the spinal cord, and this coexpression is increased during pregnancy or after estrogen and progesterone treatment (Gintzler et al., 2008). ER $\alpha$ activation contributes to increased DYN release in the spinal cord, possibly through ER $\alpha$-mediated activation of PKA and MAPK pathways (Gintzler et al., 2008). An alternate, but not mutually exclusive, possibility is that membrane bound ERs increase neuronal excitability through activation of metabotropic glutamate receptors (Boulware et al., 2005). In addition to coexpression of ER $\alpha$ and DYN, delta opioid receptors (DORs) are expressed on DYN terminals in the dorsal horn. Under normal (non-pregnant) conditions, DOR activation inhibits DYN release in the spinal cord and attenuates KOR-mediated analgesia. However, during pregnancy, this effect is switched such that DOR activation stimulates DYN release and facilitates gestational antinociception. Although the mechanisms underlying this switch in DOR function are not understood, it is likely mediated by effects of ER activation on 


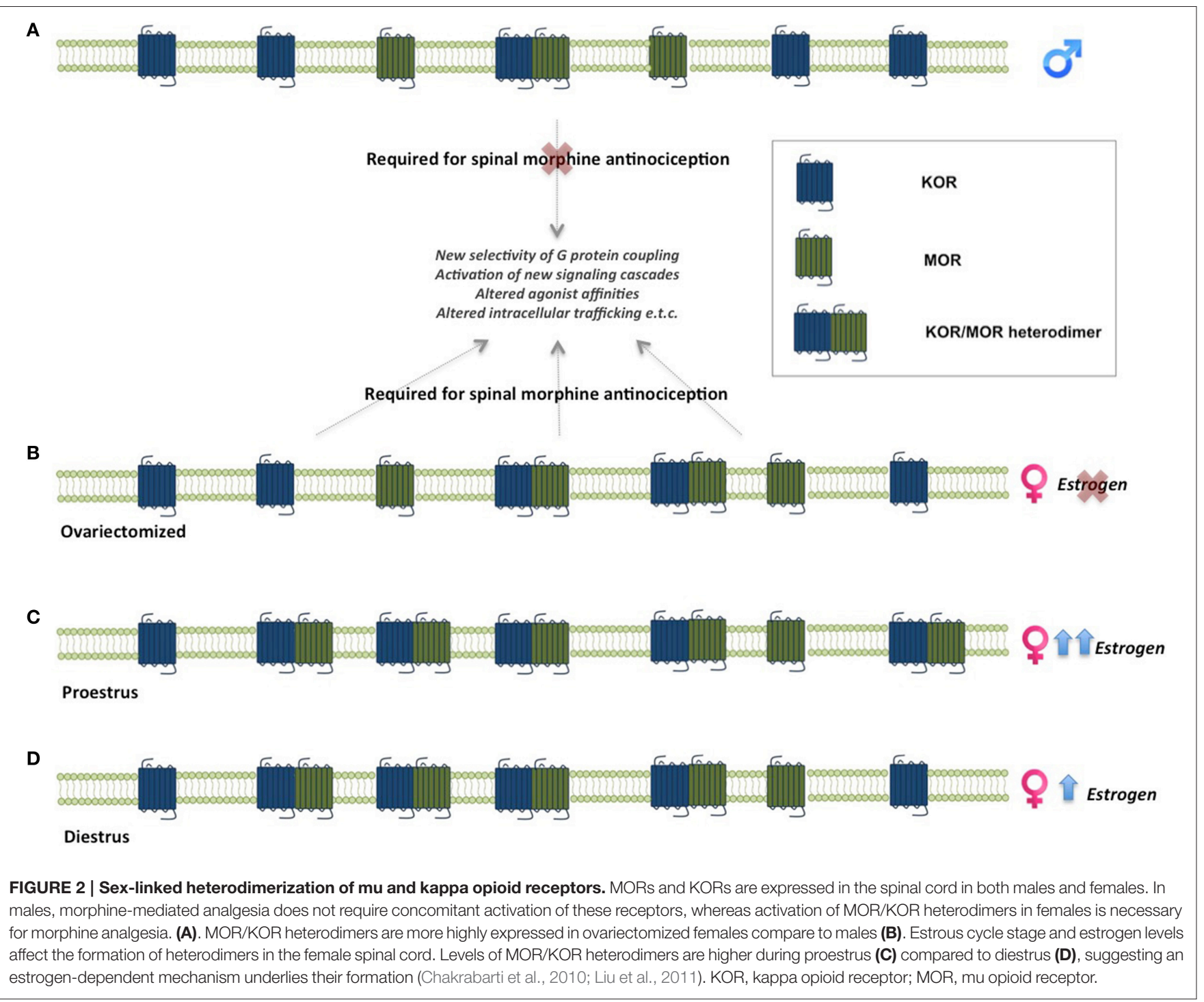

intracellular signaling events that alter DOR G-protein coupling from inhibitory to excitatory (Gintzler et al., 2008).

\section{APPLYING MECHANISMS OF SEX DIFFERENCES IN KOR/DYN SYSTEMS FROM PAIN AND OTHER SYSTEMS TO DRUG ADDICTION}

There are at least two ways in which mechanistic studies of sex differences in KOR/DYN systems within pain circuits can apply to drug addiction. First, many of the brain regions subserving pain are also important for reward and affective states (see Figure 1), raising the possibility that sex differences in pain modulation-particularly the affective component of pain-also hold true for sex differences in addiction. As one example, MC1Rs and KORs are colocalized in the periaqueductal gray (PAG) and locus coeruleus (LC), two brain regions important for sensory and affective dimensions of pain (Caruso et al., 2014) as well as somatic and affective dimensions of opiate withdrawal (Williams et al., 2001). There is evidence that KOR activation is necessary for morphine withdrawal-induced conditioned place aversions (Kelsey et al., 2015). Although not yet studied, it is possible that KOR-mediated aversive effects of morphine withdrawal in females depends on MC1Rs. The second way in which mechanisms underlying sex differences in KOR function can apply to addiction is that molecular and biochemical processes are typically similar across brain regions. What makes the functional difference is the neural circuit within which the processes are found. As one example, sex-linked polymorphisms in the pDYN gene will result in alterations in DYN in all cells. The effect these alterations have will depend on the particular cell type and brain region studied.

\section{FUTURE DIRECTIONS}

Major technical advances in genetics, molecular biology, and neurophysiology have enabled the discovery of genes, cellular mechanisms and neural circuits necessary for the transition from drug use to drug addiction. Most of these advances have been 
made selectively in male animal models, but fortunately more and more research is being conducted on males and females in parallel. In our view, it is essential to keep in mind that sex differences occur at multiple levels (McCarthy and Arnold, 2011). Of particular importance to this review, sex differences can manifest as behavioral differences in which the average behavior is different in males and females. This type of sex difference is the most commonly reported and includes the discussed differences in pain thresholds, analgesic efficacy of KOR ligands, and aversive effects of KOR activation, to name a few. These behavioral differences suggest that there are distinct underlying molecular mechanisms between males and females. Another level at which sex differences can occur is when behavioral endpoints are the same in males and females, but underlying neural mechanisms differ. This type of sex difference is often missed since there is no overt sex difference in behavior. An example of this is the female requirement for MC1R activation but male requirement for NMDA receptor activation in KOR-mediated analgesia.

A primary goal of this review was to synthesize what is known about sex differences in DYN and KOR systems and relate this to drug addiction. At this point, very little is known that directly connects sex differences in DYN and KOR function with sex differences in drug addiction. We identify three major gaps in knowledge:

(1) Are there sex differences in how DYN and KORs contribute to different facets of addictive behavior (e.g., acquisition, maintenance, dependence, withdrawal, craving, and relapse)?

(2) Are there sex differences in DYN and KOR expression levels and patterns, DYN release, and KOR coupling to downstream effectors within neural circuits that modulate

\section{REFERENCES}

Abraham, K. E., Brewer, K. L., and McGinty, J. F. (2000). Opioid peptide messenger RNA expression is increased at spinal and supraspinal levels following excitotoxic spinal cord injury. Neuroscience 99, 189-197. doi: 10.1016/S03064522(00)00150-0

Al-Hasani, R., and Bruchas, M. R. (2011). Molecular mechanisms of opioid receptor-dependent signaling and behavior. Anesthesiology 115, 1363-1381. doi: 10.1097/aln.0b013e318238bba6

Arvidsson, U., Riedl, M., Chakrabarti, S., Vulchanova, L., Lee, J. H., Nakano, A. H., et al. (1995). The kappa-opioid receptor is primarily postsynaptic: combined immunohistochemical localization of the receptor and endogenous opioids. Proc. Natl. Acad. Sci. U.S.A. 92, 5062-5066. doi: 10.1073/pnas.92.11.5062

Auyeung, B., Lombardo, M. V., and Baron-Cohen, S. (2013). Prenatal and postnatal hormone effects on the human brain and cognition. Pflugers Arch. 465, 557-571. doi: 10.1007/s00424-013-1268-2

Bals-Kubik, R., Herz, A., and Shippenberg, T. S. (1989). Evidence that the aversive effects of opioid antagonists and kappa-agonists are centrally mediated. Psychopharmacology (Berl). 98, 203-206. doi: 10.1007/BF00444692

Balthazart, J., and Ball, G. F. (2006). Is brain estradiol a hormone or a neurotransmitter? Trends Neurosci. 29, 241-249. doi: 10.1016/j.tins.2006.03.004

Barrett, A. C., Cook, C. D., Terner, J. M., Roach, E. L., Syvanthong, C., and Picker, M. J. (2002). Sex and rat strain determine sensitivity to kappa opioid-induced antinociception. Psychopharmacology (Berl). 160, 170-181. doi: 10.1007/s00213-001-0949-2

Bastiaens, M. T., ter Huurne, J. A., Kielich, C., Gruis, N. A., Westendorp, R. G., Vermeer, B. J., et al. (2001). Melanocortin-1 receptor gene variants determine addictive behavior (e.g., mesocorticolimbic system, extended amygdala, hypothalamic pituitary adrenal [HPA] axis)?

(3) Is the function of DYN and KORs within these addictionrelated neural circuits dependent on gonadal hormones? If so, what are the mechanisms?

Based on genetic association studies of the pDYN gene in drug-dependent populations (Clarke et al., 2009; Yuferov et al., 2009) and the known mechanisms underlying KOR function in antinociception described in the preceding section, we propose and encourage similar studies in animal models of drug addiction. For example, is there evidence for KOR/MOR heterodimers in limbic brain circuits? Are either MC1R or NMDA receptors necessary for KOR-mediated effects on motivated behavior? Can steroid hormone receptors modulate transcription of DYN or KOR or modify KOR-mediated intracellular signaling pathways in limbic circuits? Given the impact of negative affect on the maintenance of addiction, delineating the underlying mechanisms in both males and females will allow the development of treatments that are maximally effective in each sex.

\section{AUTHOR CONTRIBUTIONS}

EC and MM contributed equally to the literature research, organizing, writing, and editing of this review article.

\section{FUNDING}

This work was supported by the National Institute on Drug Abuse grant DA033526 (to EC) and the Jonathan E Brooking Fellowship (to MM).

the risk of nonmelanoma skin cancer independently of fair skin and red hair. Am. J. Hum. Genet. 68, 884-894. doi: 10.1086/319500

Beardsley, P. M., Howard, J. L., Shelton, K. L., and Carroll, F. I. (2005). Differential effects of the novel kappa opioid receptor antagonist, JDTic, on reinstatement of cocaine-seeking induced by footshock stressors vs cocaine primes and its antidepressant-like effects in rats. Psychopharmacology (Berl). 183, 118-126. doi: 10.1007/s00213-005-0167-4

Beato, M. (1989). Gene regulation by steroid hormones. Cell 56, 335-344. doi: 10.1016/0092-8674(89)90237-7

Becker, J. B., Arnold, A. P., Berkley, K. J., Blaustein, J. D., Eckel, L. A., Hampson, E., et al. (2005). Strategies and methods for research on sex differences in brain and behavior. Endocrinology 146, 1650-1673. doi: 10.1210/en. 2004-1142

Becker, J. B., Perry, A. N., and Westenbroek, C. (2012). Sex differences in the neural mechanisms mediating addiction: a new synthesis and hypothesis. Biol. Sex Differ. 3:14. doi: 10.1186/2042-6410-3-14

Belknap, J. K., Lamé, M., and Danielson, P. W. (1990). Inbred strain differences in morphine-induced analgesia with the hot plate assay: a reassessment. Behav. Genet. 20, 333-338. doi: 10.1007/BF01067800

Berkley, K. J. (1997). Sex differences in pain. Behav. Brain Sci. 20, 371-380; discussion: 435-513. doi: 10.1017/S0140525X97221485

Besse, D., Lombard, M. C., Zajac, J. M., Roques, B. P., and Besson, J. M. (1990). Pre- and postsynaptic distribution of $\mathrm{mu}$, delta and kappa opioid receptors in the superficial layers of the cervical dorsal horn of the rat spinal cord. Brain Res. 521, 15-22. doi: 10.1016/0006-8993(90)91519-M

Bodkin, J. A., Zornberg, G. L., Lukas, S. E., and Cole, J. O. (1995). Buprenorphine treatment of refractory depression. J. Clin. Psychopharmacol. 15, 49-57. doi: 10.1097/00004714-199502000-00008 
Bodnar, R. J., and Kest, B. (2010). Sex differences in opioid analgesia, hyperalgesia, tolerance and withdrawal: central mechanisms of action and roles of gonadal hormones. Horm. Behav. 58, 72-81. doi: 10.1016/j.yhbeh.2009.09.012

Botticelli, L. J., Cox, B. M., and Goldstein, A. (1981). Immunoreactive dynorphin in mammalian spinal cord and dorsal root ganglia. Proc. Natl. Acad. Sci. U.S.A. 78, 7783-7786. doi: 10.1073/pnas.78.12.7783

Boulware, M. I., Weick, J. P., Becklund, B. R., Kuo, S. P., Groth, R. D., and Mermelstein, P. G. (2005). Estradiol activates group I and II metabotropic glutamate receptor signaling, leading to opposing influences on cAMP response element-binding protein. J. Neurosci. 25, 5066-5078. doi: 10.1523/JNEUROSCI.1427-05.2005

Bruchas, M. R., and Chavkin, C. (2010). Kinase cascades and ligand-directed signaling at the kappa opioid receptor. Psychopharmacology (Berl). 210, 137-147. doi: 10.1007/s00213-010-1806-y

Bruchas, M. R., Land, B. B., and Chavkin, C. (2010). The dynorphin/kappa opioid system as a modulator of stress-induced and pro-addictive behaviors. Brain Res. 1314, 44-55. doi: 10.1016/j.brainres.2009.08.062

Bruchas, M. R., Xu, M., and Chavkin, C. (2008). Repeated swim stress induces kappa opioid-mediated activation of extracellular signal-regulated kinase 1/2. Neuroreport 19, 1417-1422. doi: 10.1097/WNR.0b013e32830dd655

Cahill, C. M., Taylor, A. M., Cook, C., Ong, E., Morón, J. A., and Evans, C. J. (2014). Does the kappa opioid receptor system contribute to pain aversion? Front. Pharmacol. 5:253. doi: 10.3389/fphar.2014.00253

Carey, A. N., Borozny, K., Aldrich, J. V., and McLaughlin, J. P. (2007). Reinstatement of cocaine place-conditioning prevented by the peptide kappaopioid receptor antagonist arodyn. Eur. J. Pharmacol. 569, 84-89. doi: 10.1016/j.ejphar.2007.05.007

Carlezon, W. A. Jr., Béguin, C., DiNieri, J. A., Baumann, M. H., Richards, M. R., Todtenkopf, M. S., et al. (2006). Depressive-like effects of the kappaopioid receptor agonist salvinorin A on behavior and neurochemistry in rats. J. Pharmacol. Exp. Ther. 316, 440-447. doi: 10.1124/jpet.105.092304

Carlezon, W. A. Jr., and Chartoff, E. H. (2007). Intracranial self-stimulation (ICSS) in rodents to study the neurobiology of motivation. Nat. Protoc. 2, 2987-2995. doi: 10.1038/nprot.2007.441

Carlezon, W. A. J., Bèguin, C., Knoll, A. T., and Cohen, B. M. (2009). Kappa-opioid ligands in the study and treatment of mood disorders. Pharmacol. Ther. 123, 334-343. doi: 10.1016/j.pharmthera.2009.05.008

Carroll, M. E., Lynch, W. J., Roth, M. E., Morgan, A. D., and Cosgrove, K. P. (2004). Sex and estrogen influence drug abuse. Trends Pharmacol. Sci. 25, 273-279. doi: 10.1016/j.tips.2004.03.011

Caruso, V., Lagerström, M. C., Olszewski, P. K., Fredriksson, R., and Schiöth, H. B. (2014). Synaptic changes induced by melanocortin signalling. Nat. Rev. Neurosci. 15, 98-110. doi: 10.1038/nrn3657

Chakrabarti, S., Liu, N. J., and Gintzler, A. R. (2010). Formation of mu/kappa-opioid receptor heterodimer is sex-dependent and mediates femalespecific opioid analgesia. Proc. Natl. Acad. Sci. U.S.A. 107, 20115-20119. doi: 10.1073/pnas. 1009923107

Chappell, P. B., Leckman, J. F., Scahill, L. D., Hardin, M. T., Anderson, G., and Cohen, D. J. (1993). Neuroendocrine and behavioral effects of the selective kappa agonist spiradoline in Tourette's syndrome: a pilot study. Psychiatry Res. 47, 267-280. doi: 10.1016/0165-1781(93)90084-T

Chartoff, E., Sawyer, A., Rachlin, A., Potter, D., Pliakas, A., and Carlezon, W. A. (2012). Blockade of kappa opioid receptors attenuates the development of depressive-like behaviors induced by cocaine withdrawal in rats. Neuropharmacology 62, 167-176. doi: 10.1016/j.neuropharm.2011.06.014

Chartoff, E. H., Ebner, S. R., Sparrow, A., Potter, D., Baker, P. M., Ragozzino, M. E., et al. (2015). Relative timing between kappa opioid receptor activation and cocaine determines the impact on reward and dopamine release. Neuropsychopharmacology. doi: 10.1038/npp.2015.226. [Epub ahead of print].

Chartoff, E. H., Potter, D., Damez-Werno, D., Cohen, B. M., and Carlezon, W. A. Jr. (2008). Exposure to the selective kappa-opioid receptor agonist salvinorin A modulates the behavioral and molecular effects of cocaine in rats. Neuropsychopharmacology 33, 2676-2687. doi: 10.1038/sj.npp.1301659

Chavkin, C. (2013). Dynorphin-still an extraordinarily potent opioid peptide. Mol. Pharmacol. 83, 729-736. doi: 10.1124/mol.112.083337

Chavkin, C., Bakhit, C., and Bloom, F. E. (1983). Evidence for dynorphin-A as a neurotransmitter in rat hippocampus. Life Sci. 33(Suppl. 1), 13-16. doi: $10.1016 / 0024-3205(83) 90432-0$
Chavkin, C., and Goldstein, A. (1981). Specific receptor for the opioid peptide dynorphin: structure-activity relationships. Proc. Natl. Acad. Sci. U.S.A. 78, 6543-6547. doi: 10.1073/pnas.78.10.6543

Chavkin, C., James, I. F., and Goldstein, A. (1982). Dynorphin is a specific endogenous ligand of the kappa opioid receptor. Science 215, 413-415. doi: 10.1126/science.6120570

Chen, J., Zhang, R., Chen, X., Wang, C., Cai, X., Liu, H., et al. (2015). Heterodimerization of human orexin receptor 1 and kappa opioid receptor promotes protein kinase A/cAMP-response element binding protein signaling via a Gas-mediated mechanism. Cell. Signal. 27, 1426-1438. doi: 10.1016/j.cellsig.2015.03.027

Chen, X., Grisham, W., and Arnold, A. P. (2009). X chromosome number causes sex differences in gene expression in adult mouse striatum. Eur. J. Neurosci. 29, 768-776. doi: 10.1111/j.1460-9568.2009.06610.x

Clarke, T. K., Ambrose-Lanci, L., Ferraro, T. N., Berrettini, W. H., Kampman, K. M., Dackis, C. A., et al. (2012). Genetic association analyses of PDYN polymorphisms with heroin and cocaine addiction. Genes Brain Behav. 11, 415-423. doi: 10.1111/j.1601-183X.2012.00785.x

Clarke, T. K., Krause, K., Li, T., and Schumann, G. (2009). An association of prodynorphin polymorphisms and opioid dependence in females in a Chinese population. Addict. Biol. 14, 366-370. doi: 10.1111/j.1369-1600.2009.00151.x

Cogan, R., and Spinnato, J. A. (1986). Pain and discomfort thresholds in late pregnancy. Pain 27, 63-68. doi: 10.1016/0304-3959(86)90223-X

Cohen, B. M., and Murphy, B. (2008). The effects of pentazocine, a kappa agonist, in patients with mania. Int. J. Neuropsychopharmacol. 11, 243-247. doi: 10.1017/S1461145707008073

Cole, R. L., Konradi, C., Douglass, J., and Hyman, S. E. (1995). Neuronal adaptation to amphetamine and dopamine: molecular mechanisms of prodynorphin gene regulation in rat striatum. Neuron 14, 813-823. doi: 10.1016/08966273(95) $90225-2$

Collaer, M. L., and Hines, M. (1995). Human behavioral sex differences: a role for gonadal hormones during early development? Psychol. Bull. 118, 55-107. doi: 10.1037/0033-2909.118.1.55

Cowan, A. (2003). Buprenorphine: new pharmacological aspects. Int. J. Clin. Pract. 133, 3-8; discussion: 23-24.

Craft, R. M., and Bernal, S. A. (2001). Sex differences in opioid antinociception: kappa and 'mixed action' agonists. Drug Alcohol Depend. 63, 215-228. doi: 10.1016/S0376-8716(00)00209-X

Craft, R. M., Kruzich, P. J., Boyer, J. S., Harding, J. W., and Hanesworth, J. M. (1998). Sex differences in discriminative stimulus and diuretic effects of the kappa opioid agonist U69,593 in the rat. Pharmacol. Biochem. Behav. 61, 395-403. doi: 10.1016/S0091-3057(98)00124-5

Crowley, N. A., and Kash, T. L. (2015). Kappa opioid receptor signaling in the brain: Circuitry and implications for treatment. Prog. Neuropsychopharmacol. Biol. Psychiatry 62, 51-60. doi: 10.1016/j.pnpbp.2015.01.001

Dawson-Basoa, M., and Gintzler, A. R. (1998). Gestational and ovarian sex steroid antinociception: synergy between spinal kappa and delta opioid systems. Brain Res. 794, 61-67. doi: 10.1016/S0006-8993(98)00192-9

de Curtis, M., and Paré, D. (2004). The rhinal cortices: a wall of inhibition between the neocortex and the hippocampus. Prog. Neurobiol. 74, 101-110. doi: 10.1016/j.pneurobio.2004.08.005

Dewing, P., Chiang, C. W., Sinchak, K., Sim, H., Fernagut, P. O., Kelly, S., et al. (2006). Direct regulation of adult brain function by the male-specific factor SRY. Curr. Biol. 16, 415-420. doi: 10.1016/j.cub.2006.01.017

Donzanti, B. A., Althaus, J. S., Payson, M. M., and Von Voigtlander, P. F. (1992). Kappa Agonist-Induced Reduction in Dopamine Release - Site of Action and Tolerance. Res. Commun. Chem. Pathol. Pharmacol. 78, 193-210.

Douglass, J., McKinzie, A. A., and Pollock, K. M. (1994). Identification of multiple DNA elements regulating basal and protein kinase A-induced transcriptional expression of the rat prodynorphin gene. Mol. Endocrinol. 8, 333-344.

Douglass, J., McMurray, C. T., Garrett, J. E., Adelman, J. P., and Calavetta, L. (1989). Characterization of the rat prodynorphin gene. Mol. Endocrinol. 3, 2070-2078. doi: 10.1210/mend-3-12-2070

Drake, C. T., Terman, G. W., Simmons, M. L., Milner, T. A., Kunkel, D. D., Schwartzkroin, P. A., et al. (1994). Dynorphin opioids present in dentate granule cells may function as retrograde inhibitory neurotransmitters. J. Neurosci. 14, 3736-3750. 
Ebner, S. R., Roitman, M. F., Potter, D. N., Rachlin, A. B., and Chartoff, E. H. (2010). Depressive-like effects of the kappa opioid receptor agonist salvinorin A are associated with decreased phasic dopamine release in the nucleus accumbens. Psychopharmacology (Berl). 210, 241-252. doi: 10.1007/s00213-010-1836-5

Ehrich, E., Turncliff, R., Du, Y., Leigh-Pemberton, R., Fernandez, E., Jones, R., et al. (2015). Evaluation of opioid modulation in major depressive disorder. Neuropsychopharmacology 40, 1448-1455. doi: 10.1038/npp.2014.330

Ehrich, J. M., Phillips, P. E., and Chavkin, C. (2014). Kappa opioid receptor activation potentiates the cocaine-induced increase in evoked dopamine release recorded in vivo in the mouse nucleus accumbens. Neuropsychopharmacology 39, 3036-3048. doi: 10.1038/npp.2014.157

Elkabes, S., and Nicot, A. B. (2014). Sex steroids and neuroprotection in spinal cord injury: a review of preclinical investigations. Exp. Neurol. 259, 28-37. doi: 10.1016/j.expneurol.2014.01.008

Emrich, H. M., Vogt, P., and Herz, A. (1982). Possible antidepressive effects of opioids: action of buprenorphine. Ann. N.Y. Acad. Sci. 398, 108-112. doi: 10.1111/j.1749-6632.1982.tb39483.x

Feng, Y., Weijdegård, B., Wang, T., Egecioglu, E., Fernandez-Rodriguez, J., Huhtaniemi, I., et al. (2010). Spatiotemporal expression of androgen receptors in the female rat brain during the oestrous cycle and the impact of exogenous androgen administration: a comparison with gonadally intact males. Mol. Cell. Endocrinol. 321, 161-174. doi: 10.1016/j.mce.2010.02.029

Fillingim, R. B. (2000). Sex, gender, and pain: women and men really are different. Curr. Rev. Pain 4, 24-30. doi: 10.1007/s11916-000-0006-6

Fillingim, R. B., Ness, T. J., Glover, T. L., Campbell, C. M., Price, D. D., and Staud, R. (2004). Experimental pain models reveal no sex differences in pentazocine analgesia in humans. Anesthesiology 100, 1263-1270. doi: 10.1097/00000542200405000-00031

Ford, C. P., Mark, G. P., and Williams, J. T. (2006). Properties and opioid inhibition of mesolimbic dopamine neurons vary according to target location. J. Neurosci. 26, 2788-2797. doi: 10.1523/JNEUROSCI.4331-05.2006

Forman, L. J., Tingle, V., Estilow, S., and Cater, J. (1989). The response to analgesia testing is affected by gonadal steroids in the rat. Life Sci. 45, 447-454. doi: 10.1016/0024-3205(89)90631-0

Fox, H. C., and Sinha, R. (2009). Sex differences in drug-related stress-system changes: implications for treatment in substance-abusing women. Harv. Rev. Psychiatry 17, 103-119. doi: 10.1080/10673220902899680

Fraser, H. F., and Rosenberg, D. E. (1964). Studies on the human addiction liability of 2'-Hydroxy-5-9-Dimethyl-2-(3,3-Dimethylallyl)-6,7-Benzomorphan (Win 20,228): a weak narcotic antagonist. J. Pharmacol. Exp. Ther. 143, 149-156.

Fuentealba, J. A., Gysling, K., and Andrés, M. E. (2007). Increased locomotor response to amphetamine induced by the repeated administration of the selective kappa-opioid receptor agonist U-69593. Synapse 61, 771-777. doi: 10.1002/syn.20424

Fuentealba, J. A., Gysling, K., Magendzo, K., and Andrés, M. E. (2006). Repeated administration of the selective kappa-opioid receptor agonist U69593 increases stimulated dopamine extracellular levels in the rat nucleus accumbens. J. Neurosci. Res. 84, 450-459. doi: 10.1002/jnr.20890

Gear, R. W., Gordon, N. C., Heller, P. H., Paul, S., Miaskowski, C., and Levine, J. D. (1996). Gender difference in analgesic response to the kappa-opioid pentazocine. Neurosci. Lett. 205, 207-209. doi: 10.1016/0304-3940(96)12402-2

Gear, R. W., Miaskowski, C., Gordon, N. C., Paul, S. M., Heller, P. H., and Levine, J. D. (1999). The kappa opioid nalbuphine produces gender- and dosedependent analgesia and antianalgesia in patients with postoperative pain. Pain 83, 339-345. doi: 10.1016/S0304-3959(99)00119-0

Gerra, G., Fantoma, A., and Zaimovic, A. (2006). Naltrexone and buprenorphine combination in the treatment of opioid dependence. J. Psychopharmacol. (Oxford). 20, 806-814. doi: 10.1177/0269881106060835

Gintzler, A. R., and Liu, N. J. (2012). Importance of sex to pain and its amelioration; relevance of spinal estrogens and its membrane receptors. Front. Neuroendocrinol. 33, 412-424. doi: 10.1016/j.yfrne.2012.09.004

Gintzler, A. R., Schnell, S. A., Gupta, D. S., Liu, N. J., and Wessendorf, M. W. (2008). Relationship of spinal dynorphin neurons to delta-opioid receptors and estrogen receptor alpha: anatomical basis for ovarian sex steroid opioid antinociception. J. Pharmacol. Exp. Ther. 326, 725-731. doi: 10.1124/jpet.108.139816

Gonzalez, D., Riba, J., Bouso, J. C., Gómez-Jarabo, G., and Barbanoj, M. J. (2006). Pattern of use and subjective effects of Salvia divinorum among recreational users. Drug Alcohol Depend. 85, 157-162. doi: 10.1016/j.drugalcdep.2006.04.001

Goodfellow, P. N., and Lovell-Badge, R. (1993). SRY and sex determination in mammals. Annu. Rev. Genet. 27, 71-92. doi: 10.1146/annurev.ge.27.120193.000443

Gottsch, M. L., Navarro, V. M., Zhao, Z., Glidewell-Kenney, C., Weiss, J., Jameson, J. L., et al. (2009). Regulation of Kiss1 and dynorphin gene expression in the murine brain by classical and nonclassical estrogen receptor pathways. J. Neurosci. 29, 9390-9395. doi: 10.1523/JNEUROSCI.0763-09.2009

Gouardères, C., Kopp, N., Cros, J., and Quirion, R. (1986). Kappa opioid receptors in human lumbo-sacral spinal cord. Brain Res. Bull. 16, 355-361. doi: 10.1016/0361-9230(86)90056-0

Graziane, N. M., Polter, A. M., Briand, L. A., Pierce, R. C., and Kauer, J. A. (2013). Kappa opioid receptors regulate stress-induced cocaine seeking and synaptic plasticity. Neuron 77, 942-954. doi: 10.1016/j.neuron.2012.12.034

Greenfield, S. F., Back, S. E., Lawson, K., and Brady, K. T. (2010). Substance abuse in women. Psychiatr. Clin. North Am. 33, 339-355. doi: 10.1016/j.psc.2010.01.004

Griffin, M. L., Weiss, R. D., Mirin, S. M., and Lange, U. (1989). A Comparison of Male and Female Cocaine Abusers. Arch. Gen. Psychiatry 46, 122-126. doi: 10.1001/archpsyc.1989.01810020024005

Gruber, C. J., Gruber, D. M., Gruber, I. M., Wieser, F., and Huber, J. C. (2004). Anatomy of the estrogen response element. Trends Endocrinol. Metab. 15, 73-78. doi: 10.1016/j.tem.2004.01.008

Grudt, T. J., and Williams, J. T. (1995). Opioid receptors and the regulation of ion conductances. Rev. Neurosci. 6, 279-286. doi: 10.1515/REVNEURO.1995.6.3.279

Gu, G., Rojo, A. A., Zee, M. C., Yu, J., and Simerly, R. B. (1996). Hormonal regulation of CREB phosphorylation in the anteroventral periventricular nucleus. J. Neurosci. 16, 3035-3044.

Gupta, D. S., Kelson, A. B., Polgar, W. E., Toll, L., Szücs, M., and Gintzler, A. R. (2001). Ovarian sex steroid-dependent plasticity of nociceptin/orphanin FQ and opioid modulation of spinal dynorphin release. J. Pharmacol. Exp. Ther. 298, 1213-1220.

Hamson, D. K., Jones, B. A., and Watson, N. V. (2004). Distribution of androgen receptor immunoreactivity in the brainstem of male rats. Neuroscience 127, 797-803. doi: 10.1016/j.neuroscience.2004.06.006

Han, J. S., and Xie, C. W. (1982). Dynorphin: potent analgesic effect in spinal cord of the rat. Life Sci. 31, 1781-1784. doi: 10.1016/0024-3205(82)90209-0

Han, J. S., and Xie, C. W. (1984). Dynorphin: potent analgesic effect in spinal cord of the rat. Sci. Sin. B 27, 169-177.

Hanes, K. R. (2001). Antidepressant effects of the herb Salvia divinorum: a case report. J. Clin. Psychopharmacol. 21, 634-635. doi: 10.1097/00004714200112000-00025

Harris, J. A., Chang, P. C., and Drake, C. T. (2004). Kappa opioid receptors in rat spinal cord: sex-linked distribution differences. Neuroscience 124, 879-890. doi: 10.1016/j.neuroscience.2003.12.042

Heidbreder, C. A., Babovic-Vuksanovic, D., Shoaib, M., and Shippenberg, T. S. (1995). Development of behavioral sensitization to cocaine: influence of kappa opioid receptor agonists. J. Pharmacol. Exp. Ther. 275, 150-163.

Heidbreder, C. A., Schenk, S., Partridge, B., and Shippenberg, T. S. (1998). Increased responsiveness of mesolimbic and mesostriatal dopamine neurons to cocaine following repeated administration of a selective kappa-opioid receptor agonist. Synapse 30, 255-262.

Horikawa, S., Takai, T., Toyosato, M., Takahashi, H., Noda, M., Kakidani, H., et al. (1983). Isolation and structural organization of the human preproenkephalin B gene. Nature 306, 611-614. doi: 10.1038/306611a0

Hurd, Y. L., and Herkenham, M. (1993). Molecular alterations in the neostriatum of human cocaine addicts. Synapse 13, 357-369. doi: 10.1002/syn.890130408

Iadarola, M. J., Brady, L. S., Draisci, G., and Dubner, R. (1988). Enhancement of dynorphin gene expression in spinal cord following experimental inflammation: stimulus specificity, behavioral parameters and opioid receptor binding. Pain 35, 313-326. doi: 10.1016/0304-3959(88) 90141-8

Ji, R. R., Zhang, Q., Law, P. Y., Low, H. H., Elde, R., and Hökfelt, T. (1995). Expression of mu-, delta-, and kappa-opioid receptor-like immunoreactivities in rat dorsal root ganglia after carrageenan-induced inflammation. J. Neurosci. $15,8156-8166$. 
Karp, J. F., Butters, M. A., Begley, A. E., Miller, M. D., Lenze, E. J., Blumberger, D. M., et al. (2014). Safety, tolerability, and clinical effect of low-dose buprenorphine for treatment-resistant depression in midlife and older adults. J. Clin. Psychiatry 75, e785-e793. doi: 10.4088/JCP.13m08725

Kavaliers, M., and Choleris, E. (1997). Sex differences in N-methyl-D-aspartate involvement in kappa opioid and non-opioid predator-induced analgesia in mice. Brain Res. 768, 30-36. doi: 10.1016/S0006-8993(97)00569-6

Kavaliers, M., and Galea, L. A. (1995). Sex differences in the expression and antagonism of swim stress-induced analgesia in deer mice vary with the breeding season. Pain 63, 327-334. doi: 10.1016/0304-3959(95)00063-1

Kavaliers, M., and Innes, D. G. (1987). Sex and day-night differences in opiate-induced responses of insular wild deer mice, Peromyscus maniculatus triangularis. Pharmacol. Biochem. Behav. 27, 477-482. doi: 10.1016/00913057(87)90351-0

Kelsey, J. E., Verhaak, A. M., and Schierberl, K. C. (2015). The kappa opioid receptor antagonist, nor-binaltorphimine (nor-BNI) decreases morphine withdrawal and the consequent conditioned place aversions in rats. Behav. Br. Res. 283, 16-21. doi: 10.1016/j.bbr.2015.01.008

Kenny, P. J. (2007). Brain reward systems and compulsive drug use. Trends Pharmacol. Sci. 28, 135-141. doi: 10.1016/j.tips.2007.01.008

Kern, A., Albarran-Zeckler, R., Walsh, H. E., and Smith, R. G. (2012). Apoghrelin receptor forms heteromers with DRD2 in hypothalamic neurons and is essential for anorexigenic effects of DRD2 agonism. Neuron 73, 317-332. doi: 10.1016/j.neuron.2011.10.038

Kessler, R. C. (2003). Epidemiology of women and depression. J. Affect. Disord. 74, 5-13. doi: 10.1016/S0165-0327(02)00426-3

Klinge, C. M., Jernigan, S. C., Mattingly, K. A., Risinger, K. E., and Zhang, J. (2004). Estrogen response element-dependent regulation of transcriptional activation of estrogen receptors alpha and beta by coactivators and corepressors. J. Mol. Endocrinol. 33, 387-410. doi: 10.1677/jme.1.01541

Knoll, A. T., and Carlezon, W. A. Jr. (2010). Dynorphin, stress, and depression. Brain Res. 1314, 56-73. doi: 10.1016/j.brainres.2009.09.074

Knoll, A. T., Meloni, E. G., Thomas, J. B., Carroll, F. I., and Carlezon, W. A. Jr. (2007). Anxiolytic-like effects of kappa-opioid receptor antagonists in models of unlearned and learned fear in rats. J. Pharmacol. Exp. Ther. 323, 838-845. doi: 10.1124/jpet.107.127415

Knoll, A. T., Muschamp, J. W., Sillivan, S. E., Ferguson, D., Dietz, D. M., Meloni, E. G., et al. (2011). Kappa opioid receptor signaling in the basolateral amygdala regulates conditioned fear and anxiety in rats. Biol. Psychiatry 70, 425-433. doi: 10.1016/j.biopsych.2011.03.017

Koob, G. F. (2008). A role for brain stress systems in addiction. Neuron 59, 11-34. doi: 10.1016/j.neuron.2008.06.012

Koob, G. F., and Le Moal, M. (2008). Addiction and the brain antireward system. Annu. Rev. Psychol. 59, 29-53. doi: 10.1146/annurev.psych.59.103006.093548

Kosten, T. R., Morgan, C., and Kosten, T. A. (1990). Depressive symptoms during buprenorphine treatment of opioid abusers. J. Subst. Abuse Treat. 7, 51-54. doi: 10.1016/0740-5472(90)90035-O

Laflamme, N., Nappi, R. E., Drolet, G., Labrie, C., and Rivest, S. (1998). Expression and neuropeptidergic characterization of estrogen receptors (ERalpha and ERbeta) throughout the rat brain: anatomical evidence of distinct roles of each subtype. J. Neurobiol. 36, 357-378.

Land, B. B., Bruchas, M. R., Lemos, J. C., Xu, M., Melief, E. J., and Chavkin, C. (2008). The dysphoric component of stress is encoded by activation of the dynorphin \{kappa\}-opioid system. J. Neurosci. 28, 407-414. doi: 10.1523/JNEUROSCI.4458-07.2008

Land, B. B., Bruchas, M. R., Schattauer, S., Giardino, W. J., Aita, M., Messinger, D., et al. (2009). Activation of the kappa opioid receptor in the dorsal raphe nucleus mediates the aversive effects of stress and reinstates drug seeking. Proc. Natl. Acad. Sci. U.S.A. 106, 19168-19173. doi: 10.1073/pnas. 0910705106

Lander, E. S., and Schork, N. J. (1994). Genetic dissection of complex traits. Science 265, 2037-2048. doi: 10.1126/science.8091226

Law, P. Y., Wong, Y. H., and Loh, H. H. (2000). Molecular mechanisms and regulation of opioid receptor signaling. Annu. Rev. Pharmacol. Toxicol. 40, 389-430. doi: 10.1146/annurev.pharmtox.40.1.389

Lawson, K. P., Nag, S., Thompson, A. D., and Mokha, S. S. (2010). Sex-specificity and estrogen-dependence of kappa opioid receptor-mediated antinociception and antihyperalgesia. Pain 151, 806-815. doi: 10.1016/j.pain.2010.09.018
Le Merrer, J., Becker, J. A., Befort, K., and Kieffer, B. L. (2009). Reward processing by the opioid system in the brain. Physiol. Rev. 89, 1379-1412. doi: 10.1152/physrev.00005.2009

Limonta, P., Dondi, D., Maggi, R., Martini, L., and Piva, F. (1989). Neonatal organization of the brain opioid systems controlling prolactin and luteinizing hormone secretion. Endocrinology 124, 681-686. doi: 10.1210/endo-124-2-681

Liu, N. J., Chakrabarti, S., Schnell, S., Wessendorf, M., and Gintzler, A. R. (2011). Spinal synthesis of estrogen and concomitant signaling by membrane estrogen receptors regulate spinal kappa- and mu-opioid receptor heterodimerization and female-specific spinal morphine antinociception. J. Neurosci. 31, 11836-11845. doi: 10.1523/JNEUROSCI.1901-11.2011

Liu-Chen, L. Y. (2004). Agonist-induced regulation and trafficking of kappa opioid receptors. Life Sci. 75, 511-536. doi: 10.1016/j.lfs.2003.10.041

Lohse, M. J. (2010). Dimerization in GPCR mobility and signaling. Curr. Opin. Pharmacol. 10, 53-58. doi: 10.1016/j.coph.2009.10.007

Loyd, D. R., and Murphy, A. Z. (2008). Androgen and estrogen (alpha) receptor localization on periaqueductal gray neurons projecting to the rostral ventromedial medulla in the male and female rat. J. Chem. Neuroanat. 36, 216-226. doi: 10.1016/j.jchemneu.2008.08.001

Lumbroso, S., Sandillon, F., Georget, V., Lobaccaro, J. M., Brinkmann, A. O., Privat, A., et al. (1996). Immunohistochemical localization and immunoblotting of androgen receptor in spinal neurons of male and female rats. Eur. J. Endocrinol. 134, 626-632. doi: 10.1530/eje.0.1340626

Lynch, W. J. (2006). Sex differences in vulnerability to drug self-administration. Exp. Clin. Psychopharmacol. 14, 34-41. doi: 10.1037/1064-1297.14.1.34

Lynch, W. J., and Taylor, J. R. (2004). Sex differences in the behavioral effects of 24-h/day access to cocaine under a discrete trial procedure. Neuropsychopharmacology 29, 943-951. doi: 10.1038/sj.npp.1300389

Maekawa, K., Minami, M., Yabuuchi, K., Toya, T., Katao, Y., Hosoi, Y., et al. (1994). In situ hybridization study of mu- and kappa-opioid receptor mRNAs in the rat spinal cord and dorsal root ganglia. Neurosci. Lett. 168, 97-100. doi: 10.1016/0304-3940(94)90425-1

Mague, S. D., Pliakas, A. M., Todtenkopf, M. S., Tomasiewicz, H. C., Zhang, Y., Stevens, W. C. Jr., et al. (2003). Antidepressant-like effects of kappa-opioid receptor antagonists in the forced swim test in rats. J. Pharmacol. Exp. Ther. 305, 323-330. doi: 10.1124/jpet.102.046433

Mansour, A., Burke, S., Pavlic, R. J., Akil, H., and Watson, S. J. (1996). Immunohistochemical localization of the cloned kappa 1 receptor in the rat CNS and pituitary. Neuroscience 71, 671-690. doi: 10.1016/03064522(95)00464-5

Mansour, A., Fox, C. A., Akil, H., and Watson, S. J. (1995). Opioid-receptor mRNA expression in the rat CNS: anatomical and functional implications. Trends Neurosci. 18, 22-29. doi: 10.1016/0166-2236(95)93946-U

Mansour, A., Fox, C. A., Burke, S., Meng, F., Thompson, R. C., Akil, H., et al. (1994a). Mu, delta, and kappa opioid receptor mRNA expression in the rat CNS: an in situ hybridization study. J. Comp. Neurol. 350, 412-438. doi: $10.1002 /$ cne. 903500307

Mansour, A., Fox, C. A., Meng, F., Akil, H., and Watson, S. J. (1994b). Kappa 1 receptor mRNA distribution in the rat CNS: comparison to kappa receptor binding and prodynorphin mRNA. Mol. Cell. Neurosci. 5, 124-144. doi: 10.1006/mcne.1994.1015

Mansour, A., Khachaturian, H., Lewis, M. E., Akil, H., and Watson, S. J. (1988). Anatomy of CNS opioid receptors. Trends Neurosci. 11, 308-314. doi: 10.1016/0166-2236(88)90093-8

Marchant, N. J., Densmore, V. S., and Osborne, P. B. (2007). Coexpression of prodynorphin and corticotrophin-releasing hormone in the rat central amygdala: evidence of two distinct endogenous opioid systems in the lateral division. J. Comp. Neurol. 504, 702-715. doi: 10.1002/cne.21464

Margolis, E. B., Hjelmstad, G. O., Bonci, A., and Fields, H. L. (2003). Kappaopioid agonists directly inhibit midbrain dopaminergic neurons. J. Neurosci. 23, 9981-9986.

Margolis, E. B., Hjelmstad, G. O., Bonci, A., and Fields, H. L. (2005). Both kappa and mu opioid agonists inhibit glutamatergic input to ventral tegmental area neurons. J. Neurophysiol. 93, 3086-3093. doi: 10.1152/jn.00855.2004

Margolis, E. B., Lock, H., Chefer, V. I., Shippenberg, T. S., Hjelmstad, G. O., and Fields, H. L. (2006). Kappa opioids selectively control dopaminergic neurons projecting to the prefrontal cortex. Proc. Natl. Acad. Sci. U.S.A. 103, 2938-2942. doi: $10.1073 /$ pnas.0511159103 
Marinelli, S., Vaughan, C. W., Schnell, S. A., Wessendorf, M. W., and Christie, M. J. (2002). Rostral ventromedial medulla neurons that project to the spinal cord express multiple opioid receptor phenotypes. J. Neurosci. 22, 10847-10855.

McCarthy, M. M. (2010). How it's made: organisational effects of hormones on the developing brain. J. Neuroendocrinol. 22, 736-742. doi: 10.1111/j.13652826.2010.02021.x

McCarthy, M. M., and Arnold, A. P. (2011). Reframing sexual differentiation of the brain. Nat. Neurosci. 14, 677-683. doi: 10.1038/nn.2834

McCarthy, M. M., Arnold, A. P., Ball, G. F., Blaustein, J. D., and De Vries, G. J. (2012). Sex differences in the brain: the not so inconvenient truth. J. Neurosci. 32, 2241-2247. doi: 10.1523/JNEUROSCI.5372-11.2012

McKay, J. R., Rutherford, M. J., Cacciola, J. S., Kabasakalian-McKay, R., and Alterman, A. I. (1996). Gender differences in the relapse experiences of cocaine patients. J. Nerv. Ment. Dis. 184, 616-622. doi: 10.1097/00005053-19961000000006

McLaughlin, J. P., Land, B. B., Li, S., Pintar, J. E., and Chavkin, C. (2006). Prior activation of kappa opioid receptors by U50,488 mimics repeated forced swim stress to potentiate cocaine place preference conditioning. Neuropsychopharmacology 31, 787-794. doi: 10.1038/sj.npp.1300860

Millan, M. J., Czlonkowski, A., Lipkowski, A., and Herz, A. (1989). Kappa-opioid receptor-mediated antinociception in the rat. II. Supraspinal in addition to spinal sites of action. J. Pharmacol. Exp. Ther. 251, 342-350.

Mogil, J. S., and Bailey, A. L. (2010). Sex and gender differences in pain and analgesia. Prog. Brain Res. 186, 141-157. doi: 10.1016/b978-0-444-536303.00009-9

Mogil, J. S., and Belknap, J. K. (1997). Sex and genotype determine the selective activation of neurochemically-distinct mechanisms of swim stressinduced analgesia. Pharmacol. Biochem. Behav. 56, 61-66. doi: 10.1016/S00913057(96)00157-8

Mogil, J. S., Chesler, E. J., Wilson, S. G., Juraska, J. M., and Sternberg, W. F. (2000). Sex differences in thermal nociception and morphine antinociception in rodents depend on genotype. Neurosci. Biobehav. Rev. 24, 375-389. doi: 10.1016/S0149-7634(00)00015-4

Mogil, J. S., Sternberg, W. F., Kest, B., Marek, P., and Liebeskind, J. C. (1993). Sex differences in the antagonism of swim stress-induced analgesia: effects of gonadectomy and estrogen replacement. Pain 53, 17-25. doi: 10.1016/03043959(93)90050-Y

Mogil, J. S., Wilson, S. G., Chesler, E. J., Rankin, A. L., Nemmani, K. V., Lariviere, W. R., et al. (2003). The melanocortin-1 receptor gene mediates female-specific mechanisms of analgesia in mice and humans. Proc. Natl. Acad. Sci. U.S.A. 100, 4867-4872. doi: 10.1073/pnas.0730053100

Morris, B. J., and Herz, A. (1987). Distinct distribution of opioid receptor types in rat lumbar spinal cord. Naunyn Schmiedebergs. Arch. Pharmacol. 336, 240-243. doi: 10.1007/BF00165811

Mostari, P., Ieda, N., Deura, C., Minabe, S., Yamada, S., Uenoyama, Y., et al. (2013). dynorphin-kappa opioid receptor signaling partly mediates estrogen negative feedback effect on LH pulses in female rats. J. Reprod. Dev. 59, 266-272. doi: 10.1262/jrd.2012-193

Mu, P., Neumann, P. A., Panksepp, J., Schlüter, O. M., and Dong, Y. (2011). Exposure to cocaine alters dynorphin-mediated regulation of excitatory synaptic transmission in nucleus accumbens neurons. Biol. Psychiatry 69, 228-235. doi: 10.1016/j.biopsych.2010.09.014

Muschamp, J. W., Hollander, J. A., Thompson, J. L., Voren, G., Hassinger, L. C., Onvani, S., et al. (2014). Hypocretin (orexin) facilitates reward by attenuating the antireward effects of its cotransmitter dynorphin in ventral tegmental area. Proc. Natl. Acad. Sci. U.S.A. 111, E1648-E1655. doi: 10.1073/pnas.1315542111

Muschamp, J. W., Van't Veer, A., Parsegian, A., Gallo, M. S., Chen, M., Neve, R. L., et al. (2011). Activation of CREB in the nucleus accumbens shell produces anhedonia and resistance to extinction of fear in rats. J. Neurosci. 31, 3095-3103. doi: 10.1523/JNEUROSCI.5973-10.2011

Narita, M., Kaneko, C., Miyoshi, K., Nagumo, Y., Kuzumaki, N., Nakajima, M., et al. (2006). Chronic pain induces anxiety with concomitant changes in opioidergic function in the amygdala. Neuropsychopharmacology 31, 739-750. doi: 10.1038/sj.npp.1300858

Negus, S. S. (2004). Effects of the kappa opioid agonist U50,488 and the kappa opioid antagonist nor-binaltorphimine on choice between cocaine and food in rhesus monkeys. Psychopharmacology (Berl). 176, 204-213. doi: 10.1007/s00213-004-1878-7

Newton, S. S., Thome, J., Wallace, T. L., Shirayama, Y., Schlesinger, L., Sakai, N., et al. (2002). Inhibition of cAMP response element-binding protein or dynorphin in the nucleus accumbens produces an antidepressant-like effect. J. Neurosci. 22, 10883-10890.

Nyhuis, P. W., Gastpar, M., and Scherbaum, N. (2008). Opiate treatment in depression refractory to antidepressants and electroconvulsive therapy. J. Clin. Psychopharmacol. 28, 593-595. doi: 10.1097/JCP.0b013e31818638a4

Papka, R. E., Storey-Workley, M., Shughrue, P. J., Merchenthaler, I., Collins, J. J., Usip, S., et al. (2001). Estrogen receptor-alpha and beta- immunoreactivity and mRNA in neurons of sensory and autonomic ganglia and spinal cord. Cell Tissue Res. 304, 193-214. doi: 10.1007/s004410100363

Peckys, D., and Landwehrmeyer, G. B. (1999). Expression of mu, kappa, and delta opioid receptor messenger RNA in the human CNS: a 33P in situ hybridization study. Neuroscience 88, 1093-1135. doi: 10.1016/S0306-4522(98)00251-6

Pfeiffer, A., Brantl, V., Herz, A., and Emrich, H. M. (1986). Psychotomimesis mediated by kappa opiate receptors. Science 233, 774-776. doi: 10.1126/science.3016896

Pliakas, A. M., Carlson, R. R., Neve, R. L., Konradi, C., Nestler, E. J., and Carlezon, W. A. Jr. (2001). Altered responsiveness to cocaine and increased immobility in the forced swim test associated with elevated cAMP response element-binding protein expression in nucleus accumbens. J. Neurosci. 21, 7397-7403.

Potter, D. N., Damez-Werno, D., Carlezon, W. A. Jr., Cohen, B. M., and Chartoff, E. H. (2011). Repeated exposure to the kappa-opioid receptor agonist salvinorin A modulates extracellular signal-regulated kinase and reward sensitivity. Biol. Psychiatry 70, 744-753. doi: 10.1016/j.biopsych.2011.05.021

Prinster, S. C., Hague, C., and Hall, R. A. (2005). Heterodimerization of g proteincoupled receptors: specificity and functional significance. Pharmacol. Rev. 57, 289-298. doi: 10.1124/pr.57.3.1

Randic, M., Cheng, G., and Kojic, L. (1995). kappa-opioid receptor agonists modulate excitatory transmission in substantia gelatinosa neurons of the rat spinal cord. J. Neurosci. 15, 6809-6826.

Rasakham, K., and Liu-Chen, L. Y. (2011). Sex differences in kappa opioid pharmacology. Life Sci. 88, 2-16. doi: 10.1016/j.lfs.2010.10.007

Redila, V., and Chavkin, C. (2008). Stress-induced reinstatement of cocaine seeking is mediated by the kappa opioid system. Psychopharmacology (Berl). 200, 59-70. doi: 10.1007/s00213-008-1122-y

Revankar, C. M., Cimino, D. F., Sklar, L. A., Arterburn, J. B., and Prossnitz, E. R. (2005). A transmembrane intracellular estrogen receptor mediates rapid cell signaling. Science 307, 1625-1630. doi: 10.1126/science.1106943

Riley, J. L. III, Robinson, M. E., Wise, E. A., Myers, C. D., and Fillingim, R. B. (1998). Sex differences in the perception of noxious experimental stimuli: a meta-analysis. Pain 74, 181-187. doi: 10.1016/S0304-3959(97)00199-1

Robles, C. F., McMackin, M. Z., Campi, K. L., Doig, I. E., Takahashi, E. Y., Pride, M. C., et al. (2014). Effects of kappa opioid receptors on conditioned place aversion and social interaction in males and females. Behav. Brain Res. 262, 84-93. doi: 10.1016/j.bbr.2014.01.003

Rothman, R. B., Gorelick, D. A., Heishman, S. J., Eichmiller, P. R., Hill, B. H. Norbeck, J., et al. (2000). An open-label study of a functional opioid kappa antagonist in the treatment of opioid dependence. J. Subst. Abuse Treat. 18, 277-281. doi: 10.1016/S0740-5472(99)00074-4

Russell, S. E., Rachlin, A. B., Smith, K. L., Muschamp, J., Berry, L., Zhao, Z., et al. (2014). Sex Differences in Sensitivity to the Depressive-like Effects of the Kappa Opioid Receptor Agonist U-50488 in Rats. Biol. Psychiatry 76, 213-222. doi: 10.1016/j.biopsych.2013.07.042

Sachidanandam, R., Weissman, D., Schmidt, S. C., Kakol, J. M., Stein, L. D., Marth, G., et al. (2001). A map of human genome sequence variation containing 1.42 million single nucleotide polymorphisms. Nature 409, 928-933. doi: $10.1038 / 35057149$

Schindler, A. G., Li, S., and Chavkin, C. (2010). Behavioral stress may increase the rewarding valence of cocaine-associated cues through a dynorphin/kappaopioid receptor-mediated mechanism without affecting associative learning or memory retrieval mechanisms. Neuropsychopharmacology 35, 1932-1942. doi: 10.1038/npp. 2010.67

Scott, C. J., Clarke, I. J., and Tilbrook, A. J. (2008). The effect of testosterone and season on prodynorphin messenger RNA expression in the preoptic area-hypothalamus of the ram. Domest. Anim. Endocrinol. 34, 440-450. doi: 10.1016/j.domaniend.2008.01.001

Sershen, H., Hashim, A., and Lajtha, A. (1998). Gender differences in kappaopioid modulation of cocaine-induced behavior and NMDA-evoked dopamine release. Brain Res. 801, 67-71. doi: 10.1016/S0006-8993(98)00546-0

Shippenberg, T. S., and Rea, W. (1997). Sensitization to the behavioral effects of cocaine: modulation by dynorphin and kappa-opioid receptor agonists. 
Pharmacol. Biochem. Behav. 57, 449-455. doi: 10.1016/S0091-3057(96) 00450-9

Shippenberg, T. S., Zapata, A., and Chefer, V. I. (2007). Dynorphin and the pathophysiology of drug addiction. Pharmacol. Ther. 116, 306-321. doi: 10.1016/j.pharmthera.2007.06.011

Shughrue, P. J., Lane, M. V., and Merchenthaler, I. (1997). Comparative distribution of estrogen receptor-alpha and -beta mRNA in the rat central nervous system. J. Comp. Neurol. 388, 507-525.

Shyu, W. C., Morgenthien, E. A., Pittman, K. A., and Barbhaiya, R. H. (1994). The effects of age and sex on the systemic availability and pharmacokinetics of transnasal butorphanol. Eur. J. Clin. Pharmacol. 47, 57-60. doi: 10.1007/BF00193479

Sibille, K. T., Kindler, L. L., Glover, T. L., Gonzalez, R. D., Staud, R., Riley, J. L. III, et al. (2011). Individual differences in morphine and butorphanol analgesia: a laboratory pain study. Pain Med. 12, 1076-1085. doi: 10.1111/j.15264637.2011.01157.x

Simerly, R. B., Chang, C., Muramatsu, M., and Swanson, L. W. (1990). Distribution of androgen and estrogen receptor mRNA-containing cells in the rat brain: an in situ hybridization study. J. Comp. Neurol. 294, 76-95. doi: $10.1002 /$ cne.902940107

Simmons, M. L., and Chavkin, C. (1996). Endogenous opioid regulation of hippocampal function. Int. Rev. Neurobiol. 39, 145-196. doi: 10.1016/S00747742(08)60666-2

Simonin, F., Gavériaux-Ruff, C., Befort, K., Matthes, H., Lannes, B., Micheletti, G., et al. (1995). kappa-Opioid receptor in humans: cDNA and genomic cloning, chromosomal assignment, functional expression, pharmacology, and expression pattern in the central nervous system. Proc. Natl. Acad. Sci. U.S.A. 92, 7006-7010. doi: 10.1073/pnas.92.15.7006

Slowe, S. J., Simonin, F., Kieffer, B., and Kitchen, I. (1999). Quantitative autoradiography of mu-,delta- and kappa1 opioid receptors in kappa-opioid receptor knockout mice. Brain Res. 818, 335-345. doi: 10.1016/S00068993(98)01201-3

Spanagel, R., Herz, A., and Shippenberg, T. S. (1992). Opposing tonically active endogenous opioid systems modulate the mesolimbic dopaminergic pathway. Proc. Natl. Acad. Sci. U.S.A. 89, 2046-2050. doi: 10.1073/pnas.89.6.2046

Sternberg, W. F., Chesler, E. J., Wilson, S. G., and Mogil, J. S. (2004a). Acute progesterone can recruit sex-specific neurochemical mechanisms mediating swim stress-induced and kappa-opioid analgesia in mice. Horm. Behav. 46, 467-473. doi: 10.1016/j.yhbeh.2004.05.007

Sternberg, W. F., Ritchie, J., and Mogil, J. S. (2004b). Qualitative sex differences in kappa-opioid analgesia in mice are dependent on age. Neurosci. Lett. 363, 178-181. doi: 10.1016/j.neulet.2004.04.004

Stoffel, E. C., Ulibarri, C. M., Folk, J. E., Rice, K. C., and Craft, R. M. (2005). Gonadal hormone modulation of mu, kappa, and delta opioid antinociception in male and female rats. J. Pain 6, 261-274. doi: 10.1016/j.jpain.2004.12.006

Sturm, R. A., Teasdale, R. D., and Box, N. F. (2001). Human pigmentation genes: identification, structure and consequences of polymorphic variation. Gene 277, 49-62. doi: 10.1016/S0378-1119(01)00694-1

Substance Abuse and Mental Health Services Administration (2014). "Results from the 2013 national survey on drug use and health: summary of national findings," in National Survey on Drug Use and Health Series H-48 (Rockville, MD: Department of Health and Human Services, Substance Abuse and Mental Health Services Administration) Publication No. (SMA) 14-4863.

Svingos, A. L., Colago, E. E., and Pickel, V. M. (1999). Cellular sites for dynorphin activation of kappa-opioid receptors in the rat nucleus accumbens shell. J. Neurosci. 19, 1804-1813.

Todtenkopf, M. S., Marcus, J. F., Portoghese, P. S., and Carlezon, W. A. Jr. (2004). Effects of kappa-opioid receptor ligands on intracranial self-stimulation in rats. Psychopharmacology (Berl). 172, 463-470. doi: 10.1007/s00213003-1680-y

Tomasiewicz, H. C., Todtenkopf, M. S., Chartoff, E. H., Cohen, B. M., and Carlezon, W. A. Jr. (2008). The kappa-opioid agonist U69,593 blocks cocaineinduced enhancement of brain stimulation reward. Biol. Psychiatry 64, 982-988. doi: 10.1016/j.biopsych.2008.05.029

Torres-Reveron, A., Khalid, S., Williams, T. J., Waters, E. M., Jacome, L., Luine, V. N., et al. (2009). Hippocampal dynorphin immunoreactivity increases in response to gonadal steroids and is positioned for direct modulation by ovarian steroid receptors. Neuroscience 159, 204-216. doi: 10.1016/j.neuroscience.2008.12.023
Tsuang, M. T., Lyons, M. J., Eisen, S. A., Goldberg, J., True, W., Lin, N., et al. (1996). Genetic influences on DSM-III-R drug abuse and dependence: a study of 3,372 twin pairs. Am. J. Med. Genet. 67, 473-477.

Vanderhorst, V. G., Gustafsson, J. A., and Ulfhake, B. (2005). Estrogen receptoralpha and -beta immunoreactive neurons in the brainstem and spinal cord of male and female mice: relationships to monoaminergic, cholinergic, and spinal projection systems. J. Comp. Neurol. 488, 152-179. doi: 10.1002/cne.20569

Vonvoigtlander, P. F., Lahti, R. A., and Ludens, J. H. (1983). U-50,488: a selective and structurally novel non-Mu (kappa) opioid agonist. J. Pharmacol. Exp. Ther. 224, 7-12.

Walker, B. M., and Koob, G. F. (2007). Pharmacological Evidence for a Motivational Role of [kappa]-Opioid Systems in Ethanol Dependence. Neuropsychopharmacology 33, 643-652. doi: 10.1038/sj.npp.1301438

Walker, Q. D., Rooney, M. B., Wightman, R. M., and Kuhn, C. M. (2000). Dopamine release and uptake are greater in female than male rat striatum as measured by fast cyclic voltammetry. Neuroscience 95, 1061-1070. doi: 10.1016/S0306-4522(99)00500-X

Walsh, S. L., Preston, K. L., Bigelow, G. E., and Stitzer, M. L. (1995). Acute administration of buprenorphine in humans: partial agonist and blockade effects. J. Pharmacol. Exp. Ther. 274, 361-372.

Walsh, S. L., Preston, K. L., Stitzer, M. L., Cone, E. J., and Bigelow, G. E. (1994). Clinical pharmacology of buprenorphine: ceiling effects at high doses. Clin. Pharmacol. Ther. 55, 569-580. doi: 10.1038/clpt.1994.71

Wang, D. G., Fan, J. B., Siao, C. J., Berno, A., Young, P., Sapolsky, R., et al. (1998). Large-scale identification, mapping, and genotyping of singlenucleotide polymorphisms in the human genome. Science 280, 1077-1082. doi: 10.1126/science.280.5366.1077

Wang, Y. J., Rasakham, K., Huang, P., Chudnovskaya, D., Cowan, A., and LiuChen, L. Y. (2011). Sex difference in kappa-opioid receptor (KOPR)-mediated behaviors, brain region KOPR level and KOPR-mediated guanosine 5'-O-(3[35S] thiotriphosphate) binding in the guinea pig. J. Pharmacol. Exp. Ther. 339, 438-450. doi: 10.1124/jpet.111.183905

Watkins, L. R., Wiertelak, E. P., and Maier, S. F. (1992). Kappa opiate receptors mediate tail-shock induced antinociception at spinal levels. Brain Res. 582, 1-9. doi: 10.1016/0006-8993(92)90310-6

Wee, S., Orio, L., Ghirmai, S., Cashman, J., and Koob, G. (2009). Inhibition of kappa opioid receptors attenuated increased cocaine intake in rats with extended access to cocaine. Psychopharmacology (Berl). 205, 565-575. doi: 10.1007/s00213-009-1563-y

Weissman, M. M., and Olfson, M. (1995). Depression in women: implications for health care research. Science 269, 799-801. doi: $10.1126 /$ science.7638596

Wiesenfeld-Hallin, Z. (2005). Sex differences in pain perception. Gend. Med. 2, 137-145. doi: 10.1016/S1550-8579(05)80042-7

Williams, J. T., Christie, M. J., and Manzoni, O. (2001). Cellular and synaptic adaptations mediating opioid dependence. Physiol. Rev. 81, 299-343.

Yaksh, T. L. (1997). Pharmacology and mechanisms of opioid analgesic activity. Acta Anaesthesiol. Scand. 41, 94-111. doi: 10.1111/j.1399-6576.1997.tb04623.x

Yuferov, V., Ji, F., Nielsen, D. A., Levran, O., Ho, A., Morgello, S., et al. (2009). A functional haplotype implicated in vulnerability to develop cocaine dependence is associated with reduced PDYN expression in human brain. Neuropsychopharmacology 34, 1185-1197. doi: 10.1038/npp.2008.187

Zacny, J. P., and Beckman, N. J. (2004). The effects of a cold-water stimulus on butorphanol effects in males and females. Pharmacol. Biochem. Behav. 78, 653-659. doi: 10.1016/j.pbb.2004.01.021

Zhu, J., Luo, L. Y., Li, J. G., Chen, C., and Liu-Chen, L. Y. (1997). Activation of the cloned human kappa opioid receptor by agonists enhances [35S]GTPgammaS binding to membranes: determination of potencies and efficacies of ligands. J. Pharmacol. Exp. Ther. 282, 676-684.

Conflict of Interest Statement: The authors declare that the research was conducted in the absence of any commercial or financial relationships that could be construed as a potential conflict of interest.

Copyright (C) 2015 Chartoff and Mavrikaki. This is an open-access article distributed under the terms of the Creative Commons Attribution License (CC BY). The use, distribution or reproduction in other forums is permitted, provided the original author(s) or licensor are credited and that the original publication in this journal is cited, in accordance with accepted academic practice. No use, distribution or reproduction is permitted which does not comply with these terms. 